\title{
Hope and fear for new classes of type 2 diabetes drugs: is there preclinical evidence that incretin-based therapies alter pancreatic morphology?
}

\section{Benjamin J Lamont and Sofianos Andrikopoulos}

Department of Medicine (Austin Health), The University of Melbourne, Melbourne, Victoria, Australia

Correspondence should be addressed to B J Lamont

Email

blamont@unimelb.edu.au

\begin{abstract}
Incretin-based therapies appear to offer many advantages over other approaches for treating type 2 diabetes. Some preclinical studies have suggested that chronic activation of glucagon-like peptide 1 receptor (GLP1R) signalling in the pancreas may result in the proliferation of islet $\beta$-cells and an increase in $\beta$-cell mass. This provided hope that enhancing GLP1 action could potentially alter the natural progression of type 2 diabetes. However, to date, there has been no evidence from clinical trials suggesting that GLP1R agonists or dipeptidyl peptidase-4 (DPP4) inhibitors can increase $\beta$-cell mass. Nevertheless, while the proliferative capacity of these agents remains controversial, some studies have raised concerns that they could potentially contribute to the development of pancreatitis and hence increase the risk of pancreatic cancer. Currently, there are very limited clinical data to directly assess these potential benefits and risks of incretin-based therapies. However, a review of the preclinical studies indicates that incretin-based therapies probably have only a limited capacity to regenerate pancreatic $\beta$-cells, but may be useful for preserving any remaining $\beta$-cells in type 2 diabetes. In addition, the majority of preclinical evidence does not support the notion that GLP1R agonists or DPP4 inhibitors cause pancreatitis.
\end{abstract} Key Words

$\begin{aligned} & \text { Key Words } \\ & \text { - GLP1 } \\ & \text { - DPP4 } \\ & \text { - islets } \\ & \text { - } \beta \text {-cells } \\ & \text { - pancreatitis } \\ & \text { - mice } \\ & \text { - rats }\end{aligned}$

Journal of Endocrinology (2014) 221, T43-T61

\section{Introduction}

The incretins glucagon-like peptide 1 (GLP1) and glucosedependent insulinotropic polypeptide (GIP) act via specific G-protein-coupled receptors to potentiate insulin secretion from pancreatic $\beta$-cells in a glucose-dependent manner. However, the native forms of GLP1 and GIP are rapidly inactivated in vivo by the enzyme dipeptidyl peptidase-4 (DPP4). Therefore, pharmacological approaches aimed at enhancing incretin action have focused on either utilising incretin analogues that are resistant to DPP4 cleavage or inhibiting the DPP4 enzyme. There are several GLP1 receptor (GLP1R) agonists (exenatide, liraglutide and lixisenatide) and multiple DPP4 inhibitors (sitagliptin, vildagliptin, saxagliptin, linagliptin and alogliptin) that are approved in many countries for use in patients with type 2 diabetes. A number of others are in late-stage clinical development. All these drugs act

Published by Bioscientifica Ltd.

This paper is one of five papers that form part of a thematic review section on

Incretins. The Guest Editor for this section was Martin Haluzik ${ }_{m}$ Charles University $09: 26: 10 \mathrm{AM}$

Prague, Czech Republic. 
to enhance incretin signalling not only in pancreatic $\beta$-cells, but also in other pancreatic cells and tissues expressing the relevant incretin receptors. However, due to limitations in some commonly used detection methods, the precise locations of functional incretin receptors in the pancreas outside of $\beta$-cells still remain to be fully elucidated (Drucker 2013). To date, clinical trial data have indicated that currently available incretinbased therapies have multiple beneficial effects contributing to their efficacy, but recently their safety has been questioned.

The potential benefits of enhancing GLP1 action are not limited to potentiating insulin secretion (Lovshin \& Drucker 2009). When glucose levels are elevated, GLP1 also inhibits glucagon secretion from pancreatic $\alpha$-cells, and thus the glucagon-lowering effects of GLP1R agonists and DPP4 inhibitors probably contribute to their ability to improve glycaemic control. Moreover, the effects of GLP1 are not confined to the pancreas, and the activation of GLP1R signalling in extra-pancreatic tissues such as the intestine and CNS is thought to contribute to the overall improvement in metabolic homoeostasis observed with incretin-based therapies. However, DPP4 inhibitors and GLP1R agonists modulate incretin action via different mechanisms, and the relative levels of active GLP1 (or GLP1R agonist) appear to be an important determinant of their actions. For example, pharmacological levels of GLP1R agonists reduce the rate of intestinal nutrient absorption by inhibiting the rate of gastric emptying and promote weight loss via the suppression of appetite. By contrast, DPP4 inhibitors, which result in more physiological elevations in GLP1 levels, are weight neutral and do not affect gastric emptying. Additionally, GLP1 may also have direct protective effects on the heart and cardiovascular system, and preclinical studies suggest that there may be benefits such as reduced blood pressure and reduced atherosclerosis severity associated with the use of either GLP1R agonists or DPP4 inhibitors (Ussher \& Drucker 2012).

The various actions of incretin-based therapies provide clear advantages over other available diabetes medications. For example, in contrast to the potential weight loss observed with GLP1R agonists, drugs such as insulin, sulphonylureas (SUs) and thiazolidinediones promote weight gain. In addition, while the effects of GLP1 on pancreatic hormone secretion are glucose dependent, which virtually eliminates the risk of hypoglycaemia, the actions of insulin and SUs are not dependent on elevated glucose levels, and thus therapies with these agents lead to much higher rates of hypoglycaemia. Furthermore, while non-glucose-dependent insulin secretagogues, such as SUs, may place excessive stress on pancreatic $\beta$-cells and potentially promote $\beta$-cell apoptosis (Maedler et al. 2005, Takahashi et al. 2007, Aston-Mourney et al. 2008), incretins activate signalling pathways that provide protection against apoptosis (Trumper et al. 2002, Hui et al. 2003, Wang et al. 2004). Preclinical studies in rodents have provided hope that enhancing GLP1R signalling may be able to halt the progressive decline in $\beta$-cell mass and perhaps even promote the growth of new $\beta$-cells in vivo (Xu et al. 1999, Stoffers et al. 2003). However, current techniques do not allow for the accurate assessment of $\beta$-cell mass in clinical trials, and to date, data relating incretin action to sustained improvement in $\beta$-cell function or mass in older diabetic human subjects have not been as encouraging as the initial data from rodents (Drucker 2011). So, it is worth reexamining the published preclinical studies to determine the strength of the evidence supporting the regenerative capacity of incretin-based therapies.

While the potential benefits of enhanced GLP1R signalling for $\beta$-cell mass are apparent, the putative proliferative effects of GLP1R agonists and DPP4 inhibitors raise theoretical concerns that in type 2 diabetes therapies with these agents could potentially contribute to the development of precancerous lesions. In addition, excessive proliferation of ductal cells could block the passage of digestive enzymes secreted from the exocrine pancreas. Indeed, concerns about pancreatic inflammation were revealed following several case reports of pancreatitis in patients treated with exenatide (Ahmad \& Swann 2008). Based on very limited clinical data (Elashoff et al. 2011, Singh et al. 2013) and a few preclinical studies (Matveyenko et al. 2009, Nachnani et al. 2010, Gier et al. 2012), some researchers have suggested that GLP1-based therapies increase the risk of pancreatitis (Gale 2013, Gier \& Butler 2013). Moreover, the associated publicity surrounding these issues may have contributed to an increase in the reporting of pancreatitis in US Food and Drug Administration (FDA) adverse event databases for exenatide and sitagliptin (Raschi et al. 2013). However, such self-reporting databases are prone to bias and are thus not useful for establishing the incidence of adverse events. Therefore, to determine whether there is a true effect of incretin-based therapies, it is critically important that data from well-controlled long-term studies be carefully analysed. Unfortunately, it will be some time before we have the data available from such clinical trials designed to examine the cardiovascular safety of these drugs. Currently, the only way to assess pancreatic

Published by Bioscientifica Ltd 
histology following incretin-based therapies in humans is to examine cadaver samples. However, this technique is severely limited by the lack of available donors and it is difficult to obtain appropriately matched control subjects. Indeed, a recent publication (Butler et al. 2013) that described the expansion of both the endocrine and exocrine pancreas in patients who had been treated with either sitagliptin or exenatide has been widely criticised (Drucker 2013, Engel et al. 2013, Harja et al. 2013, Heine et al. 2013, Kahn 2013, Nauck 2013, Bonner-Weir et al. 2014) for the obvious differences in age, diabetes duration and other potential confounding factors of the control group and is thus difficult to interpret. So at this stage, it appears worthwhile to carefully examine all the available preclinical studies that provide data on the effects of incretin-based therapies on the exocrine pancreas.

In summary, currently controversy and uncertainty exist as to whether incretin-based therapies alter pancreatic morphology in diabetic human subjects. Given the difficulty in obtaining useful data and material from human patients, we sought to review the available data from in vivo preclinical studies utilising GLP1R agonists or DPP4 inhibitors.

\section{GLP1R agonists and $\beta$-cell mass}

\section{Can GLP1R agonists affect $\beta$-cell mass in normal rodents?}

Normal rats One of the earliest studies to examine the effect of GLP1R agonists on pancreatic morphology demonstrated that 10-day exenatide administration ( $1 \mathrm{nmol} / \mathrm{kg}$ once daily i.p.) to $4-5$-week-old male Sprague Dawley rats increased $\beta$-cell proliferation and $\beta$-cell mass (by $\sim 40 \%$ ) (Xu et al. 1999). Another study in older (22-month-old) Wistar rats used a s.c. infusion of native GLP1 for 5 days and also reported an increase in $\beta$-cell mass immediately after the treatment period (Perfetti et al. 2000). While the administration of the GLP1R agonist liraglutide $(200 \mu \mathrm{g} / \mathrm{kg}$ twice daily s.c.) was found to be associated with increased $\beta$-cell mass in Sprague Dawley rats after 1 week of treatment, when pancreatic sections were analysed after 6 weeks of continued treatment, differences in $\beta$-cell mass were no longer detected (Bock et al. 2003). Similarly, while an increase in the number of proliferating $\beta$-cells was observed soon after the initiation of exenatide treatment (at 2 days), several studies were unable to detect any changes in $\beta$-cell proliferation at later time points (Xu et al. 1999, Perfetti et al. 2000, Stoffers et al. 2003). Therefore, in normal rats, the effect of GLP1R agonists on $\beta$-cell proliferation appears to be transient, and any effect on $\beta$-cell mass may not be durable, particularly once treatment has ceased.

Normal mice The majority of studies that have described the effects of GLP1R agonists in normal mice have been carried out using the C57BL/6 laboratory strain. This inbred mouse strain is known to expand $\beta$-cell mass in response to diet-induced obesity (Stamateris et al. 2013), so it is a good candidate for testing the effects of other potential stimuli of $\beta$-cell proliferation. Several studies in young C57BL/ 6 mice ( $<12$ weeks of age) demonstrated that exenatide (administered by daily injections or a constant s.c. infusion over a period of up to 3 weeks) increased the proportion of proliferating $\beta$-cells, as identified by markers such as bromodeoxyuridine (BrdU) incorporation and Ki67 immunopositivity (Li et al. 2003, 2005, Park et al. 2006, Rankin \& Kushner 2009, Tschen et al. 2009). Moreover, a short duration of GLP1R agonist treatment was also found to be associated with increases in islet size and $\beta$-cell mass (Stoffers et al. 2000, Park et al. 2006, Tschen et al. 2009). Similar short-term effects of exenatide treatment on $\beta$-cell proliferation were also observed in 8-week-old mice that were of mixed background $(\mathrm{C} 57 \mathrm{BL} / 6 \times \mathrm{Sv} 129$ or C57BL/6 $\times \mathrm{FVB}$; Buteau et al. 2006, Rankin \& Kushner 2009). However, changes in $\beta$-cell mass with GLP1R agonists in normal mice may not be maintained with continued treatment. An abstract presented at the annual scientific meeting of the American Diabetes Association (ADA) in 2012 revealed that treating 9-week-old B6129SF1/J (hybrid B6×Sv129) mice for 4 months with exenatide ( $1 \mathrm{nmol} / \mathrm{kg}$ per day s.c. infusion) did not affect $\beta$-cell mass (Rankin et al. 2012). Moreover, while this study observed a modest increase in the number of proliferating $\beta$-cells in mice treated with exenatide, it was less than one-third of that observed in the mice fed a high-fat diet alone. Thus, while GLP1R agonists may enhance $\beta$-cell proliferation in young mice, in comparison with other physiological stimuli, their effect may be quite small and therefore difficult to detect.

High fat-fed mice Whether GLP1R agonists can enhance $\beta$-cell mass in a situation that also requires elevated insulin secretory capacity has been examined in high fat-fed (HFF) C57BL/6 mice. In this model, starting at $\sim 8$ weeks of age, high doses of either exenatide ( $24 \mathrm{nmol} / \mathrm{kg}$ twice daily i.p. for 2 or 4 weeks) or an exenatide-albumin conjugate (CJC-1134-PC; $100 \mathrm{nmol} / \mathrm{kg}$ once daily i.p. for 4 weeks) was not able to increase $\beta$-cell mass above that of the vehicle-treated mice (Baggio et al. 2008, Lamont et al. 2012). A longer period of exenatide

Published by Bioscientifica Ltd 
treatment $(24 \mathrm{nmol} / \mathrm{kg}$ twice daily for 8 weeks) was also unable to increase $\beta$-cell mass in 16-week-old HFF mice (Lamont \& Drucker 2008). A recently published study has even observed that treatment with the longer-acting GLP1R agonist liraglutide $(0.1 \mathrm{mg} / \mathrm{kg}$ twice daily) for 6 weeks actually reduced $\beta$-cell mass in both HFF and normal chow-fed C57BL/6 mice (Ellenbroek et al. 2013). Likewise, a similar reduction in $\beta$-cell mass was accompanied by reduced rates of $\beta$-cell proliferation in HFF B6129SF1/J mice that were infused with exenatide $(1 \mathrm{nmol} / \mathrm{kg}$ per day s.c.) for 4 months (Rankin et al. 2012). Therefore, it seems that when there is a demand for increased $\beta$-cell mass and function associated with high-fat feeding, GLP1R agonist treatment is not able to further enhance the rate of $\beta$-cell proliferation. Moreover, the effect of GLP1 on the reduction of food intake and body weight may actually reduce the demand for $\beta$-cell expansion in this model of insulin resistance, leading to reduced rather than increased $\beta$-cell mass.

Young vs old mice The age of the animals is another factor that influences the ability of GLP1R agonists to modulate $\beta$-cell mass. Young rodents' $\beta$-cells have the capacity to proliferate in response to stressors such as peripheral insulin resistance induced by diet-induced obesity or loss of $\beta$-cell mass via chemicals (streptozotocin (STZ)) or surgical methods. However, the regenerative capacity of pancreatic $\beta$-cells in mice declines significantly with increasing age (Rankin \& Kushner 2009). Hence, studies carried out by several independent research groups have shown that treatment with exenatide increases $\beta$-cell proliferation in young (C57BL/6 or B6129SF1/J) mice, but has no effect on the endocrine pancreas in mice that are older than 6 months (Rankin \& Kushner 2009, Tschen et al. 2009, Lamont et al. 2012). Moreover, this lack of an effect on $\beta$-cell proliferation was found to be associated with an inability of exenatide to increase $\beta$-cell mass in studies using mice older than 6 months (Tschen et al. 2009, Lamont et al. 2012). Although one study did observe an increase in $\beta$-cell mass in 22-month-old Wistar rats that were infused with GLP1 for 5 days, there was no increase in islet cell proliferation, and as the body weights of these animals were not reported, it is not possible to assess how well the vehicle control and treatment groups were matched (Perfetti et al. 2000). Nevertheless, further evidence that GLP1R agonists can only transiently affect the morphology of the pancreatic islets in younger animals comes from preclinical safety studies. When Sprague Dawley rats or CD1 mice were administered high doses of liraglutide for 2 years, GLP1R activation did not lead to islet cell hyperplasia (Nyborg et al. 2012). Therefore, the weight of preclinical evidence suggests that GLP1R may have a very limited capacity to enhance $\beta$-cell mass in older animals.

\section{Can GLP1R agonists affect $\beta$-cell mass in diabetic rodents?}

Pancreatectomised rats While the effects of GLP1R agonists on $\beta$-cell mass in normal rodents are modest, a number of studies have examined whether these agents can affect $\beta$-cell morphology in commonly used rodent models of diabetes and obesity. One method of inducing diabetes through a loss of $\beta$-cell mass in rodents is to remove a significant amount of the pancreas through surgery. A partial pancreatectomy in young rodents results in a robust proliferative response in both the endocrine and exocrine pancreas. However, despite the apparent regenerative capacity of the pancreas in these animals, when a sufficient proportion (95\%) of the pancreas is removed, the remaining $\beta$-cells cannot cope with the required excess insulin secretory capacity and hyperglycaemia ensues (Bonner-Weir et al. 1983). Therefore, a few studies have examined whether GLP1R agonists could increase $\beta$-cell mass in this situation. In one study, exenatide was administered to 4-5-week-old Sprague Dawley rats that were hyperglycaemic due to $95 \%$ pancreatectomy, and this resulted in a significantly greater $\beta$-cell mass compared with that in vehicle-treated rats (Xu et al. 1999). However, the rates of $\beta$-cell proliferation were already increased 2.5 -fold as a result of the pancreatectomy and were not further enhanced by the administration of a GLP1R agonist (Xu et al. 1999). By contrast, a more recent study showing a similar effect of exenatide on $\beta$-cell mass in pancreatectomised rats did report significant increases in the number of proliferating (BrdU-positive) $\beta$-cells, as well as a reduction in apoptosis (Kwon et al. 2009). Interestingly, the effect of GLP1R agonists in this model may be dependent on the level of hyperglycaemia or severity of $\beta$-cell loss. For example, in $60 \%$ pancreatectomised rats, which were glucose intolerant but not hyperglycaemic, liraglutide administration for 4 days did not have any effect on $\beta$-cell proliferation or $\beta$-cell mass (Sturis et al. 2003). Overall, the data from these studies also suggest that the proliferative effect of GLP1R agonists is at best modest. Therefore, rather than promoting the regeneration of new $\beta$-cells, perhaps the protection of the remaining $\beta$-cells against apoptosis has a major role in the ability of GLP1R agonist treatment to result in an enhanced $\beta$-cell mass in this model.

Other non-obese diabetic rat models The effects of GLP1R agonists on $\beta$-cell mass have also been studied in

Published by Bioscientifica Ltd 
$\beta$-cell insufficiency models caused by non-surgical methods. The Goto-Kakizaki (GK) rat model of diabetes was generated via selective breeding of glucose-intolerant rats originally from a non-diabetic Wistar rat colony. The GK rat develops hyperglycaemia in adulthood that is associated with a 50\% reduction in $\beta$-cell mass (Movassat et al. 1995). When female GK rats were administered either GLP1 (400 $\mu \mathrm{g} / \mathrm{kg}$ once daily s.c.) or exenatide ( $3 \mu \mathrm{g} / \mathrm{kg}$ once daily s.c.) from days 2 to 6 after birth, $\beta$-cell mass was significantly greater compared with that in non-treated GK rats at 7 days and up to 2 months of age (Tourrel et al. 2002). This improvement in $\beta$-cell mass with postnatal GLP1R agonist treatment was associated with an increased number of proliferating (BrdU-positive) $\beta$-cells 1 day after the final injection. However, it should be noted that glycaemia and $\beta$-cell mass were not completely normalised when compared with control Wistar rats (Tourrel et al. 2002). These investigators used the same protocol to treat Wistar rats that had been administered STZ at birth (Tourrel et al. 2001). In this model, the number of BrdUpositive $\beta$-cells was significantly increased 7 days after STZ administration, but was not further enhanced by either GLP1 or exenatide treatment (administered from days 2 to 6). Nevertheless, there was a partial restoration of $\beta$-cell mass at 7 days and 2 months of age in these rats following the 5-day neonatal GLP1R agonist treatment. Therefore, similar to the results obtained in the partially pancreatectomised rats, these studies in STZ and GK rats support a role for GLP1R agonists in the protection of $\beta$-cells. However, while it was reported that TUNEL-positive apoptotic cells could be detected in pancreatic islets in these two studies, the authors chose not to quantify differences in apoptotic $\beta$-cells between treatment and control groups. Another study carried out in STZ-treated Sprague Dawley rats did find that a longer course of exenatide treatment ( $150 \mathrm{pmol} / \mathrm{kg}$ twice daily for 4 weeks) increased the number of (BrdU-positive) proliferating $\beta$-cells and also reduced the number of apoptotic cells within islets (Kwon et al. 2009). However, even this length of treatment only led to a partial restoration of $\beta$-cell mass, suggesting only a limited capacity of GLP1R agonists to regenerate $\beta$-cell mass.

STZ diabetic mice The ability of GLP1R agonists to protect $\beta$-cells against apoptosis has also been investigated in STZ-treated mice. Two studies have used an approach involving multiple low-dose STZ injections ( $50 \mathrm{mg} / \mathrm{kg}$ once daily i.p. for 5 days) in 8-9-week-old C57BL/6 mice, which results in a significant reduction in $\beta$-cell mass, associated with increased $\beta$-cell apoptosis and compensatory increases in $\beta$-cell proliferation, as identified by BrdU incorporation (Li et al. 2003, Maida et al. 2009). When exenatide treatment ( $24 \mathrm{nmol} / \mathrm{kg}$ twice daily) was initiated before the beginning of STZ administration and then continued until 1 or 2 days after the final STZ injection, the rates of $\beta$-cell apoptosis (assessed by TUNEL or cleaved caspase 3 immunoreactivity) were significantly reduced ( $\mathrm{Li}$ et al. 2003, Maida et al. 2009). This resulted in the maintenance of a greater $\beta$-cell mass compared with that in non-treated STZ-mice (Maida et al. 2009). However, when mice were assessed 1 month later, the $\beta$-cell mass of the exenatidetreated STZ-mice was still less than half of that of the normal control mice, and this resulted in only a mild improvement in glycaemic control (Maida et al. 2009). Moreover, even when exenatide injections were continued for up to 2 months, $\beta$-cell mass and glycaemic control in this model were improved but not normalised. Hence, these studies further illustrate the limited capacity of GLP1R agonists to regenerate $\beta$-cells and suggest that the anti-apoptotic effects of these agents may be more important for protecting the remaining $\beta$-cells, leading to the preservation of a greater $\beta$-cell mass in hyperglycaemic animals.

$\boldsymbol{d b} / \boldsymbol{d} \boldsymbol{b}$ mice The anti-apoptotic effects of GLP1R agonists have been observed in several models of diabetes precipitated by genetically determined obesity. When exenatide injections ( $1 \mathrm{nmol} / \mathrm{kg}$ once daily for 2 weeks) were initiated in female $d b / d b$ mice at 6 weeks of age, before the onset of overt hyperglycaemia, a greater $\beta$-cell mass was preserved, and the expected rise in blood glucose levels in this model at 8 weeks of age was prevented (Wang \& Brubaker 2002). In this study, exenatide treatment was found to lead to both increased $\beta$-cell proliferation (BrdU) and reduced apoptosis (TUNEL) in islets. Exenatide or liraglutide treatment in slightly older (10-11 weeks) female $d b / d b$ mice also exhibited similar positive effects on $\beta$-cell mass and proliferation (BrdU); however, blood glucose levels were not normalised (Rolin et al. 2002). Similarly, the administration of a long-acting albumin-exenatide conjugate (CJC-1131, $25 \mu \mathrm{g}$ twice daily for 4 weeks) to 7-10-week-old male $d b / d b$ mice was able to enhance $\beta$-cell proliferation, but did not completely normalise blood glucose levels (Kim et al. 2003). Therefore, to maintain good glycaemic control in $d b / d b$ mice, it appears that GLP1R agonist administration needs to be started early, before there is a significant loss of $\beta$-cell mass and function. This is consistent with a predominant protective effect of GLP1R agonists on pancreatic $\beta$-cells rather than an ability to generate significant numbers of new $\beta$-cells.

Published by Bioscientifica Ltd 
Zucker diabetic fatty rats Studies in diabetic rats have reported results similar to those reported by studies examining the effects of GLP1R agonists in mouse models. The Zucker diabetic fatty (ZDF) rat was generated by inbreeding a hyperglycaemic substrain of the Zucker fatty rat, a model of obesity resulting from the genetic disruption of leptin signalling. Consistent with their impaired glycaemic control, ZDF rats also display a reduction in $\beta$-cell mass (Finegood et al. 2001). In agreement with mouse data discussed above, several studies in ZDF rats have shown that the administration of GLP1 (30 pmol/kg per min s.c. infusion for 2 days), exenatide $(0.25 \mathrm{mg} / \mathrm{kg}$ per day s.c. infusion for 13 weeks $)$ or liraglutide ( $150 \mu \mathrm{g} / \mathrm{kg}$ twice daily s.c. for 6 weeks) can result in the maintenance of a greater $\beta$-cell mass (Farilla et al. 2002, Sturis et al. 2003, Vrang et al. 2012). In two of the three studies, this was found to be associated with an increased number of proliferating (Ki67-positive) $\beta$-cells (Farilla et al. 2002, Vrang et al. 2012). Only one of these studies reported measuring $\beta$-cell apoptosis, but did find that GLP1 also had a protective effect (Farilla et al. 2002).

Interestingly, the effect of GLP1R agonists on $\beta$-cell mass in obese rodents appears to be dependent on the relative degree of $\beta$-cell insufficiency. At 7 weeks of age, ZDF rats have a greater $\beta$-cell mass and higher rates of $\beta$-cell proliferation compared with older non-diabetic control animals; however, between 7 and 20 weeks of age, $\beta$-cell mass declines, and at 20 weeks of age, $\beta$-cell mass and the number of proliferating $\beta$-cells are no longer elevated (Vrang et al. 2012). In untreated rats, this decline in $\beta$-cell mass is associated with a progressive loss of glycaemic control; however, treatment with either GLP1 or liraglutide is able to reduce blood glucose levels in association with its effect on the preservation of a greater $\beta$-cell mass and a higher proliferation rate (Vrang et al. 2012).

\section{Can GLP1R agonists affect $\beta$-cell mass in obese (normoglycaemic) rodents?}

In addition to studies in normal rodents demonstrating that GLP1R agonists do not expand $\beta$-cell mass, studies in ZDF rats that had not yet developed hyperglycaemia showed that short-term liraglutide treatment $(200 \mu \mathrm{g} / \mathrm{kg}$ twice daily s.c. for 2 weeks) resulted in a reduced $\beta$-cell mass (Sturis et al. 2003). Similarly, when the effects of GLP1R agonist therapy were studied in Zucker fatty rats that were not on a diabetes-prone genetic background, exenatide administration $(3 \mu \mathrm{g} / \mathrm{kg}$ twice daily s.c. for 6 weeks) was also found to be associated with reduced $\beta$-cell mass (Gedulin et al. 2005). Another model of genetic obesity that does not progress to diabetes is the $o b / o b$ mouse (Coleman 1978), and in this mouse model, liraglutide administration $(100 \mu \mathrm{g} / \mathrm{kg}$ twice daily s.c. for 2 weeks) did not affect $\beta$-cell mass or proliferation (Rolin et al. 2002). Thus, in several obese models, in which there are already compensatory increases in $\beta$-cell mass, GLP1R agonists probably reduce the need for $\beta$-cell proliferation via extra-pancreatic effects on body weight and gastric emptying that improve the metabolic milieu in these animals.

\section{Is there potential for GLP1R agonists to regenerate or preserve $\beta$-cell mass in type 2 diabetes?}

The effects of GLP1R agonists on $\beta$-cell mass in rats and mice have been discussed above and are summarised in Fig. 1. While evidence in younger rodents suggests that GLP1R agonists can increase $\beta$-cell mass and proliferation, these effects are modest and may only be transient. Moreover, with advanced age and insulin resistance, the ability of GLP1R agonists to stimulate the expansion of $\beta$-cell mass is blunted. Given that the majority of clinical trials recruit obese and insulin-resistant patients with type 2 diabetes over the age of 40 years, it is perhaps not surprising that we have not seen any indirect evidence of $\beta$-cell regeneration with exenatide (Bunck et al. 2011) or liraglutide (Garber et al. 2011). However, it is possible that such agents could still be very useful for preventing further loss of $\beta$-cell mass and/or function, particularly if treatments with these agents are initiated early in the disease progression when perhaps there are still a significant number of functioning $\beta$-cells.

\section{DPP4 inhibitors and $\beta$-cell mass}

Can DPP4 inhibitors affect $\beta$-cell mass in normal rodents?

The majority of published data indicate that DPP4 inhibitors do not affect islet morphology in normal rodents. A single study in (2-day-old) neonatal Wistar rats did record a transient increase in the number of proliferating $\beta$-cells and a decrease in apoptosis associated with an increase in $\beta$-cell mass following vildagliptin administration $(60 \mathrm{mg} / \mathrm{kg}$ once daily for 3 weeks) (Duttaroy et al. 2011). Two other studies demonstrated that if vildagliptin treatment was initiated just a few weeks later (between 4 and 6 weeks of age) in this strain of rats, then no effect on $\beta$-cell mass or proliferation was detected (Maiztegui et al. 2011, Inaba et al. 2012). Similarly, treatment with other DPP4 inhibitors

Published by Bioscientifica Ltd 
Young mice

Old mice

HFF mice

STZ/diabetic mice
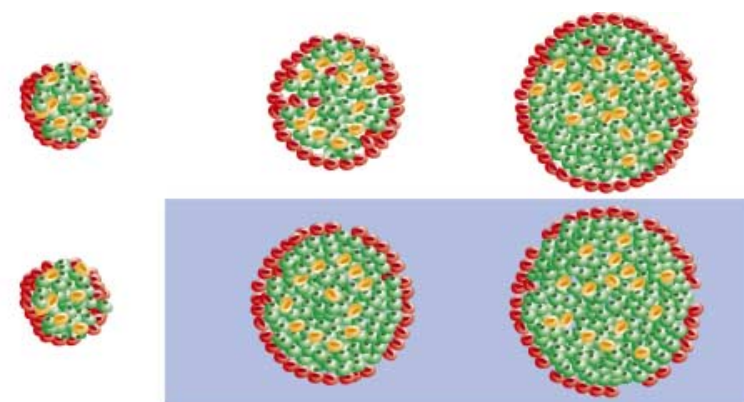

24 weeks

6 weeks

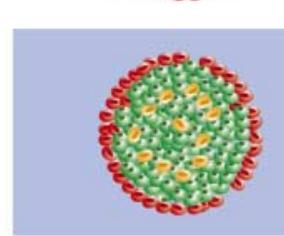

12 weeks
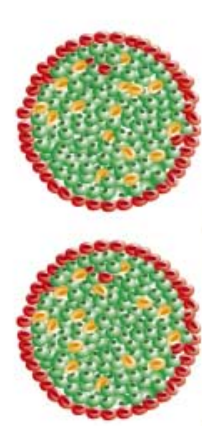

30 weeks
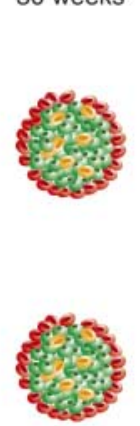

6 weeks

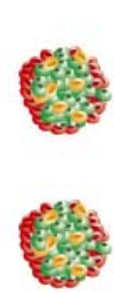

6 weeks

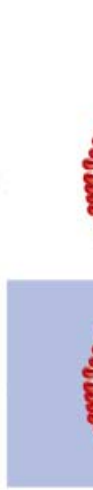

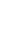
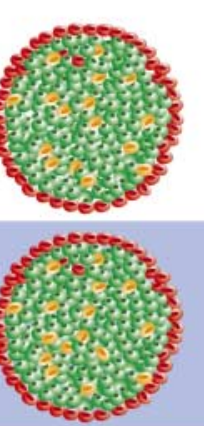

36 weeks
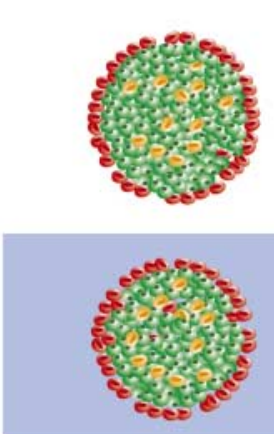

12 weeks
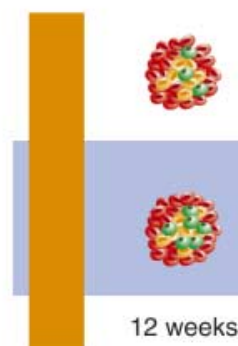

12 weeks
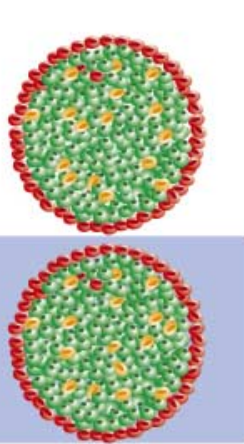

48 weeks
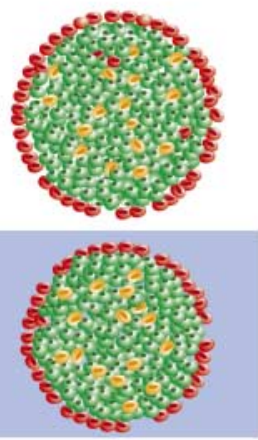

24 weeks
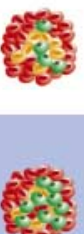

24 weeks
+ GLP1R agonist or DPP4 inhibitor
+ GLP1R

agonist
+ GLP1R

agonist

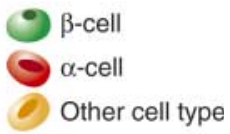

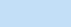


(vildagliptin, des-fluoro-sitagliptin and NVP-DPP728) for 2-5 months in young chow-fed C57BL/6 mice did not increase $\beta$-cell mass (Reimer et al. 2002, Rankin et al. 2012, Shimizu et al. 2012). Only one of these studies reported a slight increase in $\beta$-cell proliferation with des-fluoro-sitagliptin treatment, but it was only a fraction of the increase observed with high-fat feeding alone (Rankin et al. 2012). As the proliferative effects of various stimuli in mice are reduced with advanced age, it is perhaps not surprising that even 11 months of vildagliptin treatment (dose in drinking water) did not affect islet morphology in either chow-fed or HFF female C57BL/6J mice when treatment was initiated in much older (10 months) mice (Omar et al. 2013).

\section{Can DPP4 inhibitors affect $\beta$-cell mass in HFF mice?}

Multiple studies in HFF mice also indicate that DPP4 inhibitors do not promote $\beta$-cell mass expansion (Fig. 1). Short-term studies in HFF C57BL/6 mice treated with either des-fluoro-sitagliptin ( $11 \mathrm{~g} / \mathrm{kg}$ of food for 8 weeks) or vildagliptin $(0.3 \mathrm{mg} / \mathrm{ml}$ of drinking water for 20 weeks) resulted in no change in $\beta$-cell mass (Lamont \& Drucker 2008, Sato et al. 2012). Similar results were obtained when mice of the same strain were fed a sucrose +linoleic acid diet (Shirakawa et al. 2011a). Two studies reported that treatment with either NVP-DPP728 or des-fluorositagliptin decreased $\beta$-cell mass, which was associated with reduced numbers of proliferating $\beta$-cells (Reimer et al. 2002, Rankin et al. 2012). In agreement with these observations in short-term studies, a much longer treatment regimen (1 year) with sitagliptin $(3.1 \mathrm{~g} / \mathrm{kg}$ of food) in HFF C57/DBA mice was also found to be associated with reduced $\beta$-cell mass at the end of the study, compared with that in non-treated HFF mice (Aston-Mourney et al. 2013). Although DPP4 inhibitors do not reduce body weight and gastric emptying, they have been reported to be associated with improvements in insulin sensitivity (Duez et al. 2009, Shirakawa et al. 2011b), which may contribute to a reduced need for $\beta$-cell mass in the face of insulin resistance caused by a high-fat diet.

\section{Can DPP4 inhibitors affect $\beta$-cell mass in diabetic mice?}

Several groups have injected a moderate dose of STZ into HFF ICR mice in an attempt to generate a rodent model that mimics some features of type 2 diabetes. HFF-STZ mice become hyperglycaemic due to a reduction in $\beta$-cell mass in the setting of diet-induced peripheral insulin resistance ( $\mathrm{Mu}$ et al. 2006). In this model, 20-week administration of a DPP4 inhibitor (des-fluoro-sitagliptin, sitagliptin or alogliptin) resulted in the preservation of $\beta$-cell mass at levels similar to those observed in non-diabetic control mice (Mu et al. 2006, 2009, Zhang et al. 2011). While the number of proliferating islet cells increased in an attempt to compensate for the STZ-induced destruction of $\beta$-cells, sitagliptin did not further enhance the number of Ki67-positive cells detected after 20 weeks of treatment $(\mathrm{Mu}$ et al. 2009). However, both proliferation and apoptosis probably need to be examined at earlier time points.

A reduction in $\beta$-cell mass leading to sustained hyperglycaemia in C57BL/6 mice can also be achieved with the administration of a low dose of STZ $(50 \mathrm{mg} / \mathrm{kg}$ once daily) for 5 consecutive days. In this STZ mouse model, the administration of sitagliptin (or the des-fluorositagliptin analogue) before, during and immediately after the course of STZ injections led to reduced rates of $\beta$-cell apoptosis and the preservation of a greater $\beta$-cell mass, although it was not completely normalised (Maida et al. 2009, Takeda et al. 2012). There was no significant effect on the number of proliferating $\beta$-cells, but the rate of apoptosis was reduced (Takeda et al. 2012), perhaps highlighting the relative importance of the protective effects of DPP4 inhibitors for maintaining $\beta$-cell mass. Further evidence for a predominant anti-apoptotic effect of DPP4 inhibition also arises from another model of $\beta$-cell insufficiency. In young fructose-fed Wistar rats, a reduction in $\beta$-cell mass was also prevented by sitagliptin treatment $(6 \mathrm{~g} / \mathrm{kg}$ of food for 3 weeks), and this was accompanied by a reduction in $\beta$-cell apoptosis, but there was no effect on proliferation (Maiztegui et al. 2011).

\section{Can DPP4 inhibitors affect $\beta$-cell mass in obese, hyperglycaemic rodents?}

The $\beta$-cell protective effects of DPP4 inhibitors have also been observed in several genetically determined models of hyperglycaemia. Whereas incretin-based therapies have only a minimal impact on $\beta$-cell morphology in animals that are able to expand their $\beta$-cell mass in response to an obesogenic diet, in obese mice that also display $\beta$-cell deficiency associated with hyperglycaemia, it appears that DPP4 inhibitors can preserve a greater $\beta$-cell mass. In both $d b / d b$ mice and ZDF rats, the administration of des-fluorositagliptin (6-11 g/kg of food for 5-6 weeks) reduced $\beta$-cell apoptosis, although this only led to the preservation of a greater $\beta$-cell mass in the ZDF rats (Han et al. 2011, Yeom et al. 2011). By contrast, sitagliptin treatment beginning at 6 weeks of age in the Akita mouse, a non-obese model of hyperglycaemia, had no effect on $\beta$-cell mass or on the

Published by Bioscientifica Ltd 
rates of apoptosis (Yeom et al. 2011). However, the $\beta$-cell mass in these mice was less than half of that reported for the $d b / d b$ mice used in the same study, and the rates of apoptosis in Akita mouse islets at this age were also very low compared with those in the $d b / d b$ mouse islets. So perhaps, $\beta$-cell apoptosis and loss of $\beta$-cell mass occur earlier in the Akita mice and therefore DPP4 inhibitor treatment probably needs to be initiated at a younger age. Vildagliptin administration starting at 4 weeks of age ( $15 \mathrm{mg} / \mathrm{kg}$ twice daily for 18 weeks) in GK rats, which also display hyperglycaemia and $\beta$-cell insufficiency but in the absence of obesity, results in $\beta$-cell mass being maintained at levels similar to those in the control Wistar rats (Inaba et al. 2012). There was a small increase in the number of proliferating $\beta$-cells with vildagliptin treatment; however, at the end of the study, no apoptotic cells were detected in any islets, suggesting that a protective effect on $\beta$-cells may have been exerted at an earlier time point.

\section{Can DPP4 inhibitors affect $\beta$-cell mass in transgenic or knockout rodent models of $\beta$-cell deficiency?}

Studies carried out in other transgenic and knockout mice with reduced $\beta$-cell mass have reported that $\beta$-cell mass can be maintained with the administration of DPP4 inhibitors. In rats that overexpress the islet amyloidforming human islet amyloid polypeptide (hIAPP), sitagliptin treatment for 12 weeks $(200 \mathrm{mg} / \mathrm{kg}$ per day) improved, but did not completely normalise $\beta$-cell mass (Matveyenko et al. 2009). In these relatively young transgenic rats, the rates of $\beta$-cell apoptosis are very high ( $\approx 2.5$ vs $<0.05 \%$ in control animals), and sitagliptin treatment reduced this significantly. Sitagliptin treatment also led to an increase in $\beta$-cell proliferation. In a mouse model that expresses hIAPP at levels roughly equal to those of the endogenous mouse protein, sitagliptin treatment for 1 year was able to maintain $\beta$-cell mass at levels that were very similar to those in the non-transgenic control mice (Aston-Mourney et al. 2013). In other genetically modified animals, such as the Irs2 knockout and Cebpb transgenic mice, vildagliptin treatment $(0.3 \mathrm{mg} / \mathrm{ml}$ in drinking water $)$ for 20 weeks in both these strains was able to increase $\beta$-cell mass to levels approaching those observed in normal mice, and this was associated with either a reduction in apoptosis or an increase in $\beta$-cell proliferation (Sato et al. 2012, Shimizu et al. 2012). In Gck-deficient mice, sitagliptin treatment for 20 weeks was able to maintain almost normal $\beta$-cell mass, which was accompanied by a reduction in the rates of $\beta$-cell apoptosis and a small increase in proliferation (Shirakawa et al. 2011a). Therefore, the protective effects of DPP4 inhibitors are seen across multiple mouse models with reduced $\beta$-cell mass.

\section{Is there potential for DPP4 inhibitors to preserve $\beta$-cell mass in type 2 diabetes?}

Overall, the preclinical studies utilising several different agents indicate that similar to GLP1R agonists, DPP4 inhibitors have protective effects on $\beta$-cells in rodent models that display reduced $\beta$-cell mass and hyperglycaemia (Fig. 1). In studies that have compared these two therapies, it appears that both DPP4 inhibitors and GLP1R agonists have equivalent effects on the reduction of $\beta$-cell apoptosis in mice exposed to STZ (Maida et al. 2009, Takeda et al. 2012). However, there is currently a lack of studies directly comparing the effects of these two therapeutic approaches on $\beta$-cell mass.

\section{GLP1R agonists and the exocrine pancreas}

\section{Assessment of pancreatitis following incretin-based therapies}

Pancreatitis occurs as a result of the release of activated pancreatic enzymes within the pancreas. The tissue damage caused by these digestive enzymes results in pancreatic inflammation as well as oedema and, in some cases, necrosis. Pancreatitis can be caused by alterations in exocrine function or a blockage of the pancreatic ducts. In addition to the presence of abdominal pain, increased serum levels of pancreatic enzymes lipase and amylase are considered during diagnosis. As incretins could potentially affect exocrine function through either direct or indirect mechanisms and there have been case reports of pancreatitis in patients treated with all incretin-based therapies, a number of preclinical studies have examined whether incretin-based therapies affect lipase and amylase levels or alter the morphology of the exocrine pancreas. As pancreatitis is strongly correlated with the development of pancreatic cancer, the presence of such changes may also have important implications for assessing the risk of cancer with incretin-based therapies.

\section{Can GLP1R agonists affect the exocrine pancreas in normal} rodents?

Histological findings in Sprague Dawley rats Two studies examined the effect of daily administration of exenatide in normal Sprague Dawley rats (Nachnani et al. 2010, Gier et al. 2012; Table 1).

Published by Bioscientifica Ltd 
Table 1 Studies in normal young male rats and mice reporting pancreas weight and lipase or amylase levels following GLP1R agonist treatment

\begin{tabular}{|c|c|c|c|c|c|c|c|c|c|}
\hline Species & Strain & $n$ & Diet & Treatment & $\begin{array}{l}\text { Body } \\
\text { weight }\end{array}$ & $\begin{array}{l}\text { Pancreas } \\
\text { weight }\end{array}$ & Lipase & Amylase & Reference \\
\hline Rat & SD & 10 & $\begin{array}{l}\text { Normal } \\
\text { chow }\end{array}$ & $\begin{array}{l}\text { Ex, } 10 \mu \mathrm{g} / \mathrm{kg} \text { QD for } \\
11 \text { weeks }\end{array}$ & $\downarrow \downarrow \downarrow$ & - & $\uparrow$ & $\leftrightarrow$ & $\begin{array}{l}\text { Nachnani et al. } \\
\text { (2010) }\end{array}$ \\
\hline Rat & SD & 10 & $\begin{array}{l}\text { Normal } \\
\text { chow }\end{array}$ & $\begin{array}{l}\text { Ex, } 10 \mu \mathrm{g} / \mathrm{kg} \text { QD for } \\
12 \text { weeks }\end{array}$ & $\downarrow \downarrow \downarrow$ & $\leftrightarrow$ & $\leftrightarrow$ & - & Gier et al. (2012) \\
\hline Mouse & C57BL/6J & 5 & $\begin{array}{l}\text { Normal } \\
\text { chow }\end{array}$ & $\begin{array}{l}\text { Ex, } 1 \mathrm{nmol} / \mathrm{kg} \text { BID } \\
\text { for } 1 \text { week }\end{array}$ & - & $\uparrow$ & - & $\leftrightarrow$ & $\begin{array}{l}\text { Koehler et al. } \\
\text { (2009) }\end{array}$ \\
\hline Mouse & C57BL/6J & 3 & $\begin{array}{l}\text { Normal } \\
\text { chow }\end{array}$ & $\begin{array}{l}\text { Lira, } 75 \mu \mathrm{g} / \mathrm{kg} \text { BID } \\
\quad \text { for } 1 \text { week }\end{array}$ & - & $\uparrow$ & - & - & $\begin{array}{l}\text { Koehler et al. } \\
\text { (2009) }\end{array}$ \\
\hline Mouse & C57BL/6J & $13-14$ & $\begin{array}{l}\text { Normal } \\
\text { chow }\end{array}$ & $\begin{array}{l}\text { Lira, } 100 \mu \mathrm{g} / \mathrm{kg} \text { BID } \\
\quad \text { for } 6 \text { weeks }\end{array}$ & $\downarrow$ & $\uparrow$ & - & - & $\begin{array}{l}\text { Ellenbroek et al. } \\
\text { (2013) }\end{array}$ \\
\hline Mouse & C57BL/6J & 7 & High fat & $\begin{array}{l}\text { Ex, } 24 \mathrm{nmol} / \mathrm{kg} \text { BID } \\
\text { for } 4 \text { weeks }\end{array}$ & $\downarrow$ & $\uparrow$ & - & $\leftrightarrow$ & $\begin{array}{l}\text { Koehler et al. } \\
\text { (2009) }\end{array}$ \\
\hline Mouse & C57BL/6J & $4-8$ & High fat & $\begin{array}{l}\text { Ex, } 24 \mathrm{nmol} / \mathrm{kg} \text { BID } \\
\text { for } 4 \text { weeks }\end{array}$ & $\downarrow$ & $\uparrow$ & - & - & Baggio et al. (2008) \\
\hline Mouse & C57BL/6J & $13-14$ & High fat & $\begin{array}{l}\text { Lira, } 100 \mu \mathrm{g} / \mathrm{kg} \text { BID } \\
\text { for } 6 \text { weeks }\end{array}$ & $\downarrow$ & $\uparrow$ & - & - & $\begin{array}{l}\text { Ellenbroek et al. } \\
\text { (2013) }\end{array}$ \\
\hline
\end{tabular}

SD, Sprague Dawley; Ex, exenatide; Lira, liraglutide; $\downarrow \downarrow \downarrow$, large reduction (30\%); $\downarrow$, reduction (10\%); $\uparrow$, increase; $\leftrightarrow$, no difference; and -, not reported.

Both treated ten rats each $(10 \mu \mathrm{g} / \mathrm{kg}$ per day for $11-12$ weeks), and no instances of actual pancreatitis were observed in histological sections, and the typical five- to tenfold increases in serum lipase levels associated with pancreatitis were also not observed. In one study, exenatide treatment was found to result in slightly increased scores for inflammation and pyknotic nuclei in the exocrine pancreas; however, these scores were at the lower end of the reported scoring scale (mean $<10$ on a scale of $5-40$; Nachnani et al. 2010). In this cohort, serum amylase levels were not affected by exenatide treatment, but lipase levels were slightly increased $(0.46 \pm 0.12$ vs $0.28 \pm 0.07 \mathrm{U} / \mathrm{l})$. The other study reported that exenatide-treated rats did not display an increase in lipase levels, but that they did exhibit pancreatic ductal gland (PDG) hyperplasia proximal to the main pancreatic duct (Gier et al. 2012). These PDG structures can be seen in normal pancreatic sections; however, they have been shown to be increased in response to injury, and it is thought that they could give rise to pancreatic intraepithelial neoplasia (PanIN) lesions, which can be precursors to cancer (Strobel et al. 2010). This is the only study to show an effect of a GLP1R agonist on PDG proliferation, so it is not known whether it is related to this particular strain of rats. In both these Sprague Dawley rat studies, the exenatide-treated animals exhibited $\sim 30 \%$ reductions in body weight. It is not clear what effect such a substantial body weight difference may have on the function and morphology of the exocrine pancreas. It is also important to highlight that even under normal conditions the Sprague Dawley rat commonly displays histological findings in the exocrine pancreas such as focal acinar cell hypertrophy and atrophy, as well as gland-like structures in pancreatic duct sections (Chadwick et al. 2013). In addition, data from 2 -year toxicity studies with liraglutide in this strain of rats revealed no significant increase in adverse pancreatic findings (Nyborg et al. 2012). Moreover, there were also no PanIN lesions identified in ten non-human primates that were treated with liraglutide ( $5 \mathrm{mg} / \mathrm{kg}$ per day) for 87 weeks (Nyborg et al. 2012).

Effects of GLP1R agonists on pancreas weight in C57BL/6 mice Several studies in C57BL/6 mice have shown that the administration of a GLP1R agonist can result in an increase in absolute pancreas weight (Table 1). Exenatide treatment $(10 \mathrm{nmol} / \mathrm{kg}$ twice daily for 1 week) in this mouse strain resulted in a $20 \%$ increase in pancreas weight, but this was not associated with changes in susceptibility to pancreatitis, pancreatic oedema or serum amylase levels (Koehler et al. 2009). Importantly, examination of pancreatic mRNA levels in this study revealed that the expression of proinflammatory genes (Ccl2, Icam1, Stat3, Ndrg1 and Ifitm3) was not increased. However, there was a significant induction of antiinflammatory genes (Reg3a and Reg $3 b$ ), suggesting that GLP1R agonists may actually have an anti-inflammatory effect in the exocrine pancreas. Similarly, liraglutide administration to 8-9-week-old male C57BL/6 mice for a longer period of time $(0.1 \mathrm{mg} / \mathrm{kg}$ twice daily s.c. for 6 weeks)

Published by Bioscientifica Ltd 
also resulted in a $10 \%$ increase in pancreas weight, but this was not associated with any increase in the expression of proinflammatory markers (IL1B, IL6 or CCL2) in the plasma (Ellenbroek et al. 2013). Several studies have also observed increases in pancreas weight following either exenatide or liraglutide treatment for $4-8$ weeks in C57BL/6 mice that were fed a high-fat diet (Baggio et al. 2008, Lamont \& Drucker 2008, Ellenbroek et al. 2013). In chow-fed mice, the increase in pancreas weight with liraglutide treatment was found to be associated with a small increase in the proliferation of acinar cells (Ellenbroek et al. 2013). However, as there was no significant difference in the number of BrdU-positive acinar cells with liraglutide treatment in HFF animals, the mechanisms for increased pancreas weight following GLP1R agonist administration in the C57BL/6 mouse strain remain incompletely understood.

\section{Effects of GLP1R agonists on pancreas weight in}

rats In a study involving 22-month-old Wistar rats, a $20 \%$ increase in pancreas weight was observed after a 5-day GLP1 infusion ( $1.5 \mathrm{pmol} / \mathrm{kg}$ per min), and this was associated with increased markers of proliferation in the exocrine pancreas (Perfetti et al. 2000). However, increases in the number of proliferating cell nuclear antigen (PCNA)-positive ductal and exocrine cells were only observed after 2 days of GLP1 infusion, and these changes were no longer evident at 5 days. While another study in 10-week-old Sprague Dawley rats has also detected an increase in ductal cell proliferation following 12 weeks of exenatide administration, this was not actually associated with an increase in absolute pancreas weight (Gier et al. 2012). Moreover, other rodent models that have been used to assess the effect of GLP1R agonists on the pancreas have not observed an expansion in exocrine tissue (Vrang et al. 2012, Tatarkiewicz et al. 2013).

\section{Results of preclinical safety studies with GLP1R} agonists It is important to note that as part of the drug development process, substantial toxicological and carcinogenicity studies are required. As such, several studies in normal animals have been conducted to assess the safety of various GLP1R agonists including exenatide and liraglutide (Nyborg et al. 2012, Parkes et al. 2013). In these studies in which mice, rats and rabbits have been treated for up to 2 years with high doses of GLP1R agonists, there have not been any reported effects of drug treatment on the development of pancreatitis or pancreatic tumour formation. However, as these experiments were mainly carried out as part of the regulatory approval process, much of the data are not publicly available. If more of these studies were to be published in the scientific literature, it would probably improve our understanding of whether there are any potential risks of such therapies.

\section{Can GLP1R agonists affect the exocrine pancreas in obese and/or hyperglycaemic rodents?}

Although preclinical safety studies are usually carried out in normal animals, GLP1R agonists are used in patients with diabetes who may be insulin resistant and are often overweight/obese, so it seems pertinent to review the effects of such agents in animals that display similar metabolic characteristics (summarised in Table 2). When ZDF rats are administered a GLP1R agonist (either exenatide or liraglutide), glycaemic control is significantly improved (Farilla et al. 2002, Vrang et al. 2012, Tatarkiewicz et al. 2013). However, even though food intake is also reduced by these drugs, treated ZDF rats actually tend to exhibit increased body weight compared with animals in the vehicle control group (Farilla et al. 2002, Vrang et al. 2012, Tatarkiewicz et al. 2013). This may be due to the improved diabetic state following GLP1R activation. It has been observed that ZDF rats display higher rates of ductal proliferation compared with lean control animals (Vrang et al. 2012). However, the rates of proliferation in this model $(<0.1 \%)$ are still quite low and do not appear to be affected by either exenatide or liraglutide administration (Vrang et al. 2012, Tatarkiewicz et al. 2013). In these animals, the proliferation of acinar cells was shown to decrease in the ZDF rats as their glycaemic control worsens with increasing age. Exenatide treatment of ZDF rats tends to maintain the initial higher rates of acinar cell proliferation (Farilla et al. 2002, Vrang et al. 2012), perhaps as a result of the effects of improving the diabetic state. Nevertheless, despite these findings that may be suggestive of a proliferative effect in the exocrine pancreas, administration of GLP1R agonists to this diabetic rat strain did not result in increased pancreas weight (Farilla et al. 2002, Vrang et al. 2012), which is consistent with the findings of studies in normal Sprague Dawley rats.

The effects of GLP1R agonists have also been assessed in the $o b / o b$ mouse. In this obese and mildly hyperglycaemic (but non-diabetic) model, exenatide is able to lower blood glucose levels $(-0.8 \% \mathrm{HbA1c})$ and also reduce body weight by about $10 \%$ (Tatarkiewicz et al. 2010). Interestingly, even though the genetic background of $o b / o b$ mice is very close to that of the C57BL/6 mice discussed above, exenatide administration in these mice for 4 weeks did not result in any changes in pancreas weight (Tatarkiewicz et al. 2010).

Published by Bioscientifica Ltd 
Table 2 Studies in obese or hyperglycaemic male rats and mice reporting pancreas weight and lipase or amylase levels following GLP1R agonist treatment

\begin{tabular}{|c|c|c|c|c|c|c|c|c|c|}
\hline Species & Strain & $n$ & Characteristics & Treatment & $\begin{array}{l}\text { Body } \\
\text { weight }\end{array}$ & $\begin{array}{l}\text { Pancreas } \\
\text { weight }\end{array}$ & Lipase & Amylase & Reference \\
\hline Rat & $\begin{array}{l}\text { Zucker } \\
\text { fatty }\end{array}$ & $10-11$ & Obese & $\begin{array}{l}\text { Ex, } 3 \mu \mathrm{g} / \mathrm{kg} \text { BID for } \\
\quad 6 \text { weeks }\end{array}$ & $\downarrow$ & $\leftrightarrow$ & - & - & $\begin{array}{l}\text { Gedulin et al. } \\
(2005)\end{array}$ \\
\hline Mouse & $\begin{array}{c}\text { C57BL/6J } \\
\text { ob/ob }\end{array}$ & $8-10$ & Obese & $\begin{array}{l}\text { Ex, } 7.2 \mathrm{nmol} / \mathrm{kg} \\
\text { per day for } 4 \\
\text { weeks }\end{array}$ & $\downarrow$ & $\leftrightarrow$ & $\leftrightarrow$ & $\leftrightarrow$ & $\begin{array}{l}\text { Tatarkiewicz et al. } \\
\text { (2010) }\end{array}$ \\
\hline Rat & ZDF & 15 & Hyperglycaemic & $\begin{array}{l}\text { Ex, } 125 \mu \mathrm{g} / \mathrm{kg} \text { BID } \\
\text { for } 13 \text { weeks }\end{array}$ & $\uparrow$ & $\leftrightarrow$ & $\downarrow$ & $\uparrow$ & $\begin{array}{l}\text { Tatarkiewicz et al. } \\
(2013)\end{array}$ \\
\hline Rat & ZDF & 12 & Hyperglycaemic & $\begin{array}{l}\text { Ex, } 0.25 \mathrm{mg} / \mathrm{kg} \text { per } \\
\text { day for } 13 \\
\text { weeks; or Lira, } \\
1 \mathrm{mg} / \mathrm{kg} \text { QD for } \\
13 \text { weeks }\end{array}$ & $\leftrightarrow$ & $\leftrightarrow$ & $\leftrightarrow$ & $\uparrow$ & Vrang et al. (2012) \\
\hline Mouse & $\begin{array}{l}\text { C57BL/6J } \\
\text { STZ }\end{array}$ & $8-10$ & $\begin{array}{l}\text { Hyperglycaemic } \\
\text { and high fat } \\
\text { fed }\end{array}$ & $\begin{array}{l}\text { Ex, } 7.2 \mathrm{nmol} / \mathrm{kg} \\
\text { per day for } \\
4 \text { weeks }\end{array}$ & $\downarrow$ & $\leftrightarrow$ & $\leftrightarrow$ & $\leftrightarrow$ & $\begin{array}{l}\text { Tatarkiewicz et al. } \\
\quad(2010)\end{array}$ \\
\hline
\end{tabular}

STZ, streptozotocin; Ex, exenatide; Lira, liraglutide; $\downarrow$, reduction; $\uparrow$, increase; $\leftrightarrow$, no difference; and -, not reported.

In this case, histological findings were not reported; however, there were no changes in serum lipase or amylase levels associated with exenatide treatment.

Several studies have also examined the effects of GLP1R agonists in mice that have been rendered diabetic by STZ administration. Although these agents have beneficial effects on the levels of glycaemia ( $\mathrm{Li}$ et al. 2003, Kwon et al. 2009, Maida et al. 2009, Tatarkiewicz et al. 2010), only one study reported data on pancreas weight and enzyme levels. In this particular study, exenatide treatment was not found to be associated with any differences in pancreas weight or levels of pancreatic enzymes lipase and amylase (Tatarkiewicz et al. 2010).

\section{Can GLP1R agonists affect the severity of pancreatitis in rodents?}

Experimental pancreatitis Animal models have also been used to determine whether GLP1R agonists alter the severity of experimentally induced pancreatitis (Table 3). The injection of caerulein (CRN; a cholecystokinin mimetic) in rodents produces a mild form of secretagogue-induced pancreatitis that results in transient increases in plasma amylase and lipase levels as well as increased pancreas weight and inflammation (Lerch \& Gorelick 2013). In addition, a more severe form of pancreatitis can be induced by the infusion of sodium taurocholate (ST; a bile salt) into the biliopancreatic duct (Aho et al. 1980). In C57BL/6J male mice, exenatide treatment that was started 1 week before the multiple CRN injections $(5 \times 3 \mu \mathrm{g} / \mathrm{kg})$ appeared to have a somewhat protective effect, resulting in reduced levels of plasma amylase levels (Koehler et al. 2009). However, when CRN was administered at a higher dose $(5 \times 6 \mu \mathrm{g} / \mathrm{kg})$, exenatide administration started either 1 week before or immediately after the induction of pancreatitis did not have an effect on pancreatic enzyme levels (Koehler et al. 2009). Therefore, even though exenatide treatment does have an effect on pancreas weight in the C57BL/6 strain, in this setting of experimental pancreatitis, it is not due to increased oedema and does not appear to affect the severity of pancreatitis (Koehler et al. 2009). In Sprague Dawley rats, GLP1R agonists may also have a mild protective effect, as it was found that the administration of exenatide before a single dose of CRN also reduced the resulting levels of serum lipase and amylase (Tatarkiewicz et al. 2010). However, in Wistar rats in which a more severe form of pancreatitis was induced by ST, exenatide treatment for $48 \mathrm{~h}$ was unable to affect the circulating levels of these pancreatic enzymes (Tatarkiewicz et al. 2010). Therefore, while there were no histology data available for the direct assessment of pancreatitis, together the lipase and amylase levels reported in these experiments suggest that the administration of a GLP1R agonist does not worsen the severity of experimental pancreatitis and could even have some beneficial effects when the disease is mild.

\section{Pancreatitis in obese and/or diabetic} rodents Patients with type 2 diabetes have been shown to have an increased risk of developing pancreatitis (Noel et al. 2009, Girman et al. 2010). Therefore, the effects

Published by Bioscientifica Ltd 
Table 3 Studies in rodent models of pancreatitis reporting pancreas weight and lipase or amylase levels following GLP1R agonist treatment

\begin{tabular}{|c|c|c|c|c|c|c|c|c|c|}
\hline Species & Strain & $n$ & Model & Treatment & $\begin{array}{l}\text { Body } \\
\text { weight }\end{array}$ & $\begin{array}{l}\text { Pancreas } \\
\text { weight }\end{array}$ & Lipase & Amylase & Reference \\
\hline Mouse & C57BL/6J & 4 & $\begin{array}{l}\text { CRN }(3 \mu \mathrm{g} / \mathrm{kg}, \\
\text { five times } \\
\text { hourly) }\end{array}$ & $\begin{array}{l}\text { Ex, } 10 \mathrm{nmol} / \mathrm{kg} \\
\text { BID for } 1 \text { week } \\
\text { before CRN } \\
\text { injection }\end{array}$ & - & $\uparrow$ & - & $\downarrow$ & $\begin{array}{l}\text { Koehler et al. } \\
\text { (2009) }\end{array}$ \\
\hline Rat & SD & $6-7$ & $\begin{array}{l}\text { CRN }(10 \mu \mathrm{g} / \mathrm{kg}, \\
\text { single } \\
\text { injection) }\end{array}$ & $\begin{array}{l}\text { Ex, } 0.72 \mathrm{nmol} / \mathrm{kg} \\
\text { single injection } \\
15 \text { min before } \\
\text { CRN injection }\end{array}$ & - & $\leftrightarrow$ & $\downarrow$ & $\downarrow$ & $\begin{array}{l}\text { Tatarkiewicz et al. } \\
\quad(2010)\end{array}$ \\
\hline Rat & Wistar & $6-7$ & $\begin{array}{l}\text { ST (ductal } \\
\text { infusion) }\end{array}$ & $\begin{array}{l}\text { Ex, } 0.72 \mathrm{nmol} / \mathrm{kg} \\
\text { BID for } 48 \mathrm{~h}\end{array}$ & - & $\leftrightarrow$ & $\leftrightarrow$ & $\leftrightarrow$ & $\begin{array}{l}\text { Tatarkiewicz et al. } \\
\quad(2010)\end{array}$ \\
\hline Rat & ZDF & $6-7$ & $\begin{array}{l}\text { CRN }(10 \mu \mathrm{g} / \mathrm{kg}, \\
\text { single } \\
\text { injection) }\end{array}$ & $\begin{array}{l}\text { Ex, } 0.72 \mathrm{nmol} / \mathrm{kg} \\
\text { single injection } \\
15 \text { min before } \\
\text { CRN injection }\end{array}$ & - & $\leftrightarrow$ & $\leftrightarrow$ & $\leftrightarrow$ & $\begin{array}{l}\text { Tatarkiewicz et al } \\
\quad(2010)\end{array}$ \\
\hline Mouse & $\begin{array}{l}\text { C57BL/6J } \\
\text { ob/ob }\end{array}$ & $8-10$ & $\begin{array}{l}\text { CRN }(10 \mu \mathrm{g} / \mathrm{kg} \\
\text { five times } \\
\text { hourly i.p. } \\
\text { injections) }\end{array}$ & $\begin{array}{l}\text { Ex, } 7.2 \mathrm{nmol} / \mathrm{kg} \\
\text { per day for } 4 \\
\text { weeks }\end{array}$ & $\downarrow$ & $\leftrightarrow$ & $\downarrow$ & $\downarrow$ & $\begin{array}{l}\text { Tatarkiewicz et al. } \\
\quad(2010)\end{array}$ \\
\hline Mouse & $\begin{array}{l}\text { C57BL/6, } \\
\text { Pdx1-Kras }\end{array}$ & $5-7$ & $\begin{array}{c}\text { Activating Kras } \\
\text { mutation }\end{array}$ & $\begin{array}{l}\text { Ex, } 5 \mathrm{nmol} / \mathrm{kg} \text { QD } \\
\text { for } 12 \text { weeks }\end{array}$ & $\leftrightarrow$ & $\uparrow$ & $\uparrow$ & - & Gier et al. (2012) \\
\hline
\end{tabular}

SD, Sprague Dawley; CRN, caerulein; ST, sodium taurocholate; Ex, exenatide; Lira, liraglutide; $\downarrow$, reduction; $\uparrow$, increase; $\leftrightarrow$, no difference; and -, not reported.

of GLP1R agonists on experimental pancreatitis have also been investigated in rodent models of diabetes and obesity. Similar to studies in normal rats, CRN has been used to induce pancreatitis in the ZDF model. In this diabetic rat model, the prior injection of exenatide did not have any significant effects on lipase or amylase levels (Tatarkiewicz et al. 2010). Ob/ob mice appear to be more susceptible to pancreatitis, and it has been shown that the administration of CRN to these mice results in greater increases in amylase and lipase levels (Tatarkiewicz et al. 2010). Associated with this increased susceptibility to experimentally induced pancreatitis is a lower level of $R e g 3 b$ gene expression in the pancreas. When exenatide was infused for 4 weeks before the induction of pancreatitis in this model, the increases in lipase and amylase levels in $o b / o b$ mice were significantly reduced and were similar to those observed in CRN-treated control (C57BL/6) mice (Tatarkiewicz et al. 2010). Interestingly, exenatide pretreatment also enhanced the levels of pancreatic Reg $3 b$ mRNA, so that the $o b / o b$ mice in this study exhibited increases in the expression of this antiinflammatory gene similar to those observed in lean C57BL/6 mice. However, as GLP1R agonists potentially have several beneficial effects in this obese model, it is difficult to ascertain whether the improvements in measures of pancreatitis severity are due to the reduction in body weight and improved glucose homoeostasis or whether they could be due to a direct protective effect on the exocrine pancreas.

Pdx1-Kras transgenic mice An additional model of pancreatitis can be induced in rodents with an activating mutation of the Kras gene: Pdx1-Kras mice (Gier et al. 2012). This gene mutation is activated by another transgene (Cre) that is expressed in pancreatic cells under the control of the promoter sequence of the $P d x 1$ gene. These mutant mice do not display hyperglycaemia or obesity, and exenatide administered for 12 weeks at a dose of $5 \mathrm{nmol} / \mathrm{kg}$ per day did not have any effect on body weight, food intake or blood glucose levels in this model. However, these mice are on the C57BL/6 genetic background, and this treatment regimen did result in an increase in pancreas weight. In addition, markers of acinar-to-ductal metaplasia and ductal cell proliferation were reportedly increased, although there were no reports of cancerous lesions in the pancreata of these mice. In addition, slightly higher histopathology scores for pancreatitis were observed in exenatide-treated $P d x 1-K r a s$ mice than in the vehicle-treated Pdx1-Kras mice. Moreover, in contrast to the beneficial effects on enzyme levels in other models of pancreatitis, exenatide administration was found to be associated with increased plasma lipase levels. However, the effects of using a GLP1R agonist in these mice should be interpreted with some caution. The activation of

Published by Bioscientifica Ltd 
GLP1R signalling in rodent $\beta$-cells has clearly been shown to induce increased transcription of the $P d x 1$ gene (Wang et al. 1999, Stoffers et al. 2000), and as a Pdx1-driven Cre transgene was used to mediate the induction of the Kras mutation in these mice, there could be unintended effects of GLP1R agonists through this mechanism.

\section{Can GLP1R agonists cause or worsen pancreatitis in preclinical models?}

In summary, the majority of studies in laboratory animals demonstrate that GLPR agonists do not cause pancreatitis or worsen pancreatitis induced by other stimuli. In fact, there are some data suggesting that when pancreatitis is mild, exenatide may even have a beneficial effect, at least in terms of the relative levels of serum lipase and amylase. Although some conflicting results were obtained in a transgenic model of pancreatitis, overall GLP1R agonists appear to have little or no impact on lipase or amylase levels when the induction of pancreatitis is more severe.

\section{DPP4 inhibitors and the exocrine pancreas}

\section{IAPP transgenic rats}

There are only a small number of published studies examining the effects of DPP4 inhibition on the exocrine pancreas, with disparate findings even in similar transgenic animal models expressing the IIAPP gene. Transgenic rats and mice expressing a $h I A P P$ transgene under the control of the rat insulin promoter have been generated by two independent research groups to model changes that can occur in islets in type 2 diabetes. Unlike the normal rodent peptide, hIAPP forms amyloid in the pancreatic islets of transgenic animals, and this results in associated defects in islet $\beta$-cell function and survival (Hull et al. 2003, Butler et al. 2004). The HIP rat model overexpresses the hIAPP transgene at high levels in islet $\beta$-cells (Huang et al. 2007, Costes et al. 2011) and displays hyperglycaemia along with a significant loss of $\beta$-cell mass between 5 and 10 months of age (Matveyenko \& Butler 2006). At 5 months of age, pancreatic sections from HIP rats were also found to display a threefold higher rate of Ki67 immunopositivity in pancreatic ductal cells compared with control Sprague Dawley rats (Matveyenko etal. 2009). When sitagliptin was administered to these animals in the food for 12 weeks, improved glycaemia and reduced body weight were observed; however, it also resulted in a further increase in ductal cell proliferation, as assessed by the number of Ki67-immunopositive cells (Matveyenko et al. 2009). It was also reported that one of eight rats treated with sitagliptin developed severe pancreatitis. However, a recent study has demonstrated that even under normal conditions, these transgenic rats can spontaneously exhibit multiple abnormalities in the exocrine pancreas, and so it is difficult to clearly ascertain the effects of DPP4 inhibition in studies using such small numbers of animals (Chadwick et al. 2013).

\section{IAPP transgenic mice}

To further investigate the impact of long-term DPP4 inhibition on pancreatic morphology, another study treated hIAPP transgenic mice with sitagliptin for a period of 1 year (Aston-Mourney et al. 2013). This model expresses the hIAPP transgene in $\beta$-cells at levels similar to those of the endogenous mouse Iapp gene, and so it has been described as a more physiologically relevant model of islet amyloid deposition (Hull et al. 2009). In this model, the formation of islet amyloid is increased by dietary fat and is associated with the development of hyperglycaemia (Verchere et al. 1996, Hull et al. 2003). While sitagliptin treatment improved glycaemic control, there was no effect of the drug on food intake or body weight (Aston-Mourney et al. 2013). There was also no effect of sitagliptin on pancreas weight. In the hIAPP transgenic mice, the number of proliferating (Ki67-positive) ductal cells was found to be quite low $(<3 \%)$ and was not different from that in the control mice or affected by sitagliptin treatment. As such, there was no pancreatitis or abnormal duct morphology associated with chronic DPP4 inhibitor treatment in either the hIAPP transgenic or the control (non-transgenic, C57/DBA2 mixed background) mice. While periductal fibrosis, inflammatory infiltration and a few instances of focal necrosis were detected, there were no differences between the experimental groups, suggesting that these findings in the exocrine pancreas may be related to either the age of the animals or the high-fat diet used in this study.

\section{Results of preclinical safety studies with DPP4 inhibitors}

There have also been extensive preclinical toxicological and carcinogenicity safety studies carried out as a requirement for regulatory approval for the various DPP4 inhibitors that are currently available to treat type 2 diabetes patients. As a requirement for regulatory approval, these types of studies use relatively large numbers of mice and rats (50-60 animals per treatment group) and so they are quite powerful for detecting adverse effects. Most of these studies have not been published in the scientific literature, so specific details

Published by Bioscientifica Ltd 
are not readily available. However, it is important to note that there has been no increased risk of pancreatic cancer reported during the approval process for any of the currently available DPP4 inhibitors (Nauck 2013). Recently, the pancreatic histology data from the 104-week mouse and rat carcinogenicity studies for vildagliptin have been published and revealed that there is no pancreatitis or other significant histological findings in the exocrine pancreas (Busch et al. 2013). Therefore, even though pancreatitis was reported in one sitagliptin-treated transgenic HIP rat, overall the data from the majority of preclinical studies do not support the notion that DPP4 inhibition is associated with the induction of exocrine pancreatic abnormalities.

\section{Conclusions}

The current absence of available techniques to assess pancreatic morphology in clinical trial subjects means that the putative proliferative effects of incretin-based therapies are controversial. Therefore, we reviewed the published preclinical studies and found that GLP1R agonists or DPP4 inhibitors appear to have only modest and transient effects on $\beta$-cell proliferation. There is also little evidence from animal studies to suggest that incretinbased therapies contribute to the development of pancreatitis and other abnormalities in the exocrine pancreas.

\section{$\beta$-cell mass}

In contrast to some initial findings, a majority of studies now indicate that GLP1R agonists and DPP4 inhibitors have either very little or no effect on $\beta$-cell mass in normal rodents. Moreover, the effects of these incretin-based therapies on the improvement of insulin sensitivity may even lead to reduced $\beta$-cell mass in rodent models of obesity that are normally associated with $\beta$-cell expansion. The predominant action of GLP1R agonists and DPP4 inhibitors potentially affecting pancreatic morphology appears to be the preservation of $\beta$-cell mass in models of diabetes. In mice or rats that display a reduction in $\beta$-cell mass associated with hyperglycaemia, incretin-based therapies have been shown on multiple occasions to reduce $\beta$-cell apoptosis and in some cases to also preserve the normal proliferative response of $\beta$-cells to high glucose levels or other stresses. Overall, these findings suggest that for incretin-based therapies to have a beneficial effect on $\beta$-cell mass, they probably need to be used early in the progression of diabetes, when there are likely to be more functional $\beta$-cells remaining. However, the overall lack of evidence for strong in vivo proliferative actions of GLP1R agonists and DPP4 inhibitors may not only reduce the hope that therapies with these agents may be able to regenerate islet $\beta$-cells, but also dampen the fear that they could contribute to the development of pancreatitis or cancer.

\section{Pancreatitis}

Animal studies conducted in several species largely indicate that GLP1R agonists and DPP4 inhibitors do not contribute to the development of pancreatitis. Several studies have also shown that they do not worsen experimentally induced pancreatitis in rodents. While GLP1R agonists have been found to increase pancreas weight in one strain $(\mathrm{C} 57 \mathrm{BL} / 6)$ of mice, this does not appear to be associated with any clear pathology. Pancreatitis was reported in one of eight hIAPPoverexpressing transgenic rats that had been treated with sitagliptin, findings not yet reproduced by others. Even if such findings do not represent a generalisable effect of incretin-based therapies, they will probably continue to be raised in the debate on the safety of these agents. In any case, it would be unwise to either ignore or put too much emphasis on effects that are only observed in a particular strain or model. However, investigators do need to ensure that such findings are real, by using reliable experimental techniques for analysing changes in pancreatic morphology and by studying sufficient numbers of animals. We must also understand the limitations of any particular animal model that might be used and whether it is relevant to normal or diseased biology. Most importantly, the underlying genetic or phenotypic causes of atypical effects of potential or current therapeutic agents need to be properly investigated. Indeed, if we can precisely understand why some strains of mice, but not others, display adverse effects in response to drug exposure, this may help us understand which subgroups of patients are best positioned to benefit from a particular therapy and in which groups it may pose an unacceptable risk.

\section{Declaration of interest}

B $J \mathrm{~L}$ has received honoraria and travel grants from Sanofi-Aventis. He is also conducting research funded by a research grant to the University of Melbourne from Boehringer Ingelheim. S A has received honoraria and travel grants from Sanofi-Aventis, MSD, GSK, Servier, Boehringer Ingelheim, Medtronic and AZ/BMS.

\section{Funding}

Funding from NHMRC project grants has supported B J L's salary and S A holds a NHMRC Senior Research Fellowship. However, the specific research conducted in preparation of this manuscript did not receive any specific grant funding.

Published by Bioscientifica Ltd 


\section{References}

Ahmad SR \& Swann J 2008 Exenatide and rare adverse events. New England Journal of Medicine 358 1971-1972 (discussion 1971-1972). (doi:10. 1056/NEJMc0707137)

Aho HJ, Koskensalo SM \& Nevalainen TJ 1980 Experimental pancreatitis in the rat. Sodium taurocholate-induced acute haemorrhagic pancreatitis. Scandinavian Journal of Gastroenterology 15 411-416. (doi:10.3109/ 00365528009181493)

Aston-Mourney K, Proietto J, Morahan G \& Andrikopoulos S 2008 Too much of a good thing: why it is bad to stimulate the $\beta$ cell to secrete insulin. Diabetologia 51 540-545. (doi:10.1007/s00125-008-0930-2)

Aston-Mourney K, Subramanian SL, Zraika S, Samarasekera T, Meier DT, Goldstein LC \& Hull RL 2013 One year of sitagliptin treatment protects against islet amyloid-associated $\beta$-cell loss and does not induce pancreatitis or pancreatic neoplasia in mice. American Journal of Physiology. Endocrinology and Metabolism 305 E475-E484. (doi:10.1152/ ajpendo.00025.2013)

Baggio LL, Huang Q, Cao X \& Drucker DJ 2008 An albumin-exendin-4 conjugate engages central and peripheral circuits regulating murine energy and glucose homeostasis. Gastroenterology 134 1137-1147. (doi:10.1053/j.gastro.2008.01.017)

Bock T, Pakkenberg B \& Buschard K 2003 The endocrine pancreas in nondiabetic rats after short-term and long-term treatment with the longacting GLP-1 derivative NN2211. APMIS 111 1117-1124. (doi:10.1111/ j.1600-0463.2003.apm1111207.x)

Bonner-Weir S, Trent DF \& Weir GC 1983 Partial pancreatectomy in the rat and subsequent defect in glucose-induced insulin release. Journal of Clinical Investigation 71 1544-1553. (doi:10.1172/JCI110910)

Bonner-Weir S, In't Veld P \& Weir G 2014 Re-analysis of study of pancreatic effects of incretin therapy: methodological deficiencies. Diabetes, Obesity \& Metabolism [in press]. (doi:10.1111/dom.12257)

Bunck MC, Corner A, Eliasson B, Heine RJ, Shaginian RM, Taskinen MR, Smith U, Yki-Jarvinen H \& Diamant M 2011 Effects of exenatide on measures of $\beta$-cell function after 3 years in metformin-treated patients with type 2 diabetes. Diabetes Care 34 2041-2047. (doi:10.2337/ dc11-0291)

Busch SJ, Hoffmann P, Sahota P, Johnson R, Kothny W, Meyer F \& Foley JE 2013 Studies in rodents with the dipeptidyl peptidase-4 inhibitor vildagliptin to evaluate possible drug-induced pancreatic histological changes that are predictive of pancreatitis and cancer development in man. Diabetes, Obesity \& Metabolism 15 72-76. (doi:10.1111/j.14631326.2012.01678.x)

Buteau J, Spatz ML \& Accili D 2006 Transcription factor FoxO1 mediates glucagon-like peptide- 1 effects on pancreatic $\beta$-cell mass. Diabetes $\mathbf{5 5}$ 1190-1196. (doi:10.2337/db05-0825)

Butler AE, Jang J, Gurlo T, Carty MD, Soeller WC \& Butler PC 2004 Diabetes due to a progressive defect in $\beta$-cell mass in rats transgenic for human islet amyloid polypeptide (HIP rat): a new model for type 2 diabetes. Diabetes 53 1509-1516. (doi:10.2337/diabetes.53.6.1509)

Butler AE, Campbell-Thompson M, Gurlo T, Dawson DW, Atkinson M \& Butler PC 2013 Marked expansion of exocrine and endocrine pancreas with incretin therapy in humans with increased exocrine pancreas dysplasia and the potential for glucagon-producing neuroendocrine tumors. Diabetes 62 2595-2604. (doi:10.2337/db12-1686)

Chadwick KD, Fletcher AM, Parrula MC, Bonner-Weir S, Mangipudy RS, Janovitz E, Graziano MJ, Roy D \& Reilly TP 2013 Occurrence of spontaneous pancreatic lesions in normal and diabetic rats: a potential confounding factor in the nonclinical assessment of glucagon-like peptide (GLP)-1-based therapies. Diabetes [in press]. (doi:10.2337/db13-126)

Coleman DL 1978 Obese and diabetes: two mutant genes causing diabetesobesity syndromes in mice. Diabetologia 14 141-148. (doi:10.1007/ BF00429772)

Costes S, Huang CJ, Gurlo T, Daval M, Matveyenko AV, Rizza RA, Butler AE $\&$ Butler PC $2011 \beta$-Cell dysfunctional ERAD/ubiquitin/proteasome system in type 2 diabetes mediated by islet amyloid polypeptideinduced UCH-L1 deficiency. Diabetes 60 227-238. (doi:10.2337/ db10-0522)

Drucker DJ 2011 Incretin-based therapy and the quest for sustained improvements in $\beta$-cell health. Diabetes Care 34 2133-2135. (doi:10.2337/dc11-0986)

Drucker DJ 2013 Incretin action in the pancreas: potential promise, possible perils, and pathological pitfalls. Diabetes 62 3316-3323. (doi:10.2337/db13-0822)

Duez H, Smith AC, Xiao C, Giacca A, Szeto L, Drucker DJ \& Lewis GF 2009 Acute dipeptidyl peptidase-4 inhibition rapidly enhances insulinmediated suppression of endogenous glucose production in mice. Endocrinology 150 56-62. (doi:10.1210/en.2008-1137)

Duttaroy A, Voelker F, Merriam K, Zhang X, Ren X, Subramanian K, Hughes TE \& Burkey BF 2011 The DPP-4 inhibitor vildagliptin increases pancreatic $\beta$ cell mass in neonatal rats. European Journal of Pharmacology 650 703-707. (doi:10.1016/j.ejphar.2010.10.062)

Elashoff M, Matveyenko AV, Gier B, Elashoff R \& Butler PC 2011 Pancreatitis, pancreatic, and thyroid cancer with glucagon-like peptide-1-based therapies. Gastroenterology 141 150-156. (doi:10.1053/ j.gastro.2011.02.018)

Ellenbroek JH, Tons HA, Westerouen van Meeteren MJ, de Graaf N, Hanegraaf MA, Rabelink TJ, Carlotti F \& de Koning EJ 2013 Glucagonlike peptide-1 receptor agonist treatment reduces $\beta$ cell mass in normoglycaemic mice. Diabetologia 56 1980-1986. (doi:10.1007/ s00125-013-2957-2)

Engel SS, Golm GT \& Lauring B 2013 Comment on: Butler et al. Marked expansion of exocrine and endocrine pancreas with incretin therapy in humans with increased exocrine pancreas dysplasia and the potential for glucagon-producing neuroendocrine tumors. Diabetes 2013;62:2595-2604. Diabetes 62 e18. (doi:10.2337/db13-0525)

Farilla L, Hui H, Bertolotto C, Kang E, Bulotta A, Di Mario U \& Perfetti R 2002 Glucagon-like peptide-1 promotes islet cell growth and inhibits apoptosis in Zucker diabetic rats. Endocrinology 143 4397-4408. (doi:10.1210/en.2002-220405)

Finegood DT, McArthur MD, Kojwang D, Thomas MJ, Topp BG, Leonard T \& Buckingham RE $2001 \beta$-Cell mass dynamics in Zucker diabetic fatty rats, Rosiglitazone prevents the rise in net cell death. Diabetes $\mathbf{5 0}$ 1021-1029. (doi:10.2337/diabetes.50.5.1021)

Gale EA 2013 GLP-1 based agents and acute pancreatitis: drug safety falls victim to the three monkey paradigm. BMJ $346 \mathrm{f1263.} \mathrm{(doi:10.1136/}$ bmj.f1263)

Garber A, Henry RR, Ratner R, Hale P, Chang CT, Bode B \& Group L-S 2011 Liraglutide, a once-daily human glucagon-like peptide 1 analogue, provides sustained improvements in glycaemic control and weight for 2 years as monotherapy compared with glimepiride in patients with type 2 diabetes. Diabetes, Obesity \& Metabolism 13 348-356. (doi:10.1111/j.1463-1326.2010.01356.x)

Gedulin BR, Nikoulina SE, Smith PA, Gedulin G, Nielsen LL, Baron AD, Parkes DG \& Young AA 2005 Exenatide (exendin-4) improves insulin sensitivity and $\{\beta\}$-cell mass in insulin-resistant obese fa/fa Zucker rats independent of glycemia and body weight. Endocrinology 146 2069-2076. (doi:10.1210/en.2004-1349)

Gier B \& Butler PC 2013 Glucagon-like peptide 1-based drugs and pancreatitis: clarity at last, but what about pancreatic cancer? JAMA Internal Medicine 173 539-541. (doi:10.1001/jamainternmed. 2013.3374)

Gier B, Matveyenko AV, Kirakossian D, Dawson D, Dry SM \& Butler PC 2012 Chronic GLP-1 receptor activation by exendin-4 induces expansion of pancreatic duct glands in rats and accelerates formation of dysplastic lesions and chronic pancreatitis in the Kras(G12D) mouse model. Diabetes 61 1250-1262. (doi:10.2337/db11-1109)

Girman CJ, Kou TD, Cai B, Alexander CM, O’Neill EA, Williams-Herman DE \& Katz L 2010 Patients with type 2 diabetes mellitus have higher risk for acute pancreatitis compared with those without diabetes. Diabetes, Obesity \& Metabolism 12 766-771. (doi:10.1111/j.1463-1326.2010.01231.x) 
Han SJ, Choi SE, Kang Y, Jung JG, Yi SA, Kim HJ, Lee KW \& Kim DJ 2011 Effect of sitagliptin plus metformin on $\beta$-cell function, islet integrity and islet gene expression in Zucker diabetic fatty rats. Diabetes Research and Clinical Practice 92 213-222. (doi:10.1016/j.diabres. 2011.01.016)

Harja E, Lord J \& Skyler JS 2013 An analysis of characteristics of subjects examined for incretin effects on pancreatic pathology. Diabetes Technology \& Therapeutics 15 609-618. (doi:10.1089/dia.2013.0177)

Heine RJ, Fu H, Kendall DM \& Moller DE 2013 Comment on: Butler et al. Marked expansion of exocrine and endocrine pancreas with incretin therapy in humans with increased exocrine pancreas dysplasia and the potential for glucagon-producing neuroendocrine tumors. Diabetes 2013;62:2595-2604. Diabetes 62 e16-e17. (doi:10.2337/ db13-0690)

Huang CJ, Lin CY, Haataja L, Gurlo T, Butler AE, Rizza RA \& Butler PC 2007 High expression rates of human islet amyloid polypeptide induce endoplasmic reticulum stress mediated $\beta$-cell apoptosis, a characteristic of humans with type 2 but not type 1 diabetes. Diabetes 56 2016-2027. (doi:10.2337/db07-0197)

Hui H, Nourparvar A, Zhao X \& Perfetti R 2003 Glucagon-like peptide-1 inhibits apoptosis of insulin-secreting cells via a cyclic $5^{\prime}$-adenosine monophosphate-dependent protein kinase A- and a phosphatidylinositol 3-kinase-dependent pathway. Endocrinology 144 1444-1455. (doi:10.1210/en.2002-220897)

Hull RL, Andrikopoulos S, Verchere CB, Vidal J, Wang F, Cnop M, Prigeon RL \& Kahn SE 2003 Increased dietary fat promotes islet amyloid formation and $\beta$-cell secretory dysfunction in a transgenic mouse model of islet amyloid. Diabetes 52 372-379. (doi:10.2337/diabetes. 52.2.372)

Hull RL, Zraika S, Udayasankar J, Aston-Mourney K, Subramanian SL \& Kahn SE 2009 Amyloid formation in human IAPP transgenic mouse islets and pancreas, and human pancreas, is not associated with endoplasmic reticulum stress. Diabetologia 52 1102-1111. (doi:10.1007/s00125-009-1329-4)

Inaba W, Mizukami H, Kamata K, Takahashi K, Tsuboi K \& Yagihashi S 2012 Effects of long-term treatment with the dipeptidyl peptidase-4 inhibitor vildagliptin on islet endocrine cells in non-obese type 2 diabetic Goto-Kakizaki rats. European Journal of Pharmacology 691 297-306. (doi:10.1016/j.ejphar.2012.07.030)

Kahn SE 2013 Incretin therapy and islet pathology: a time for caution. Diabetes 62 2178-2180. (doi:10.2337/db13-0520)

Kim JG, Baggio LL, Bridon DP, Castaigne JP, Robitaille MF, Jette L, Benquet C \& Drucker DJ 2003 Development and characterization of a glucagonlike peptide 1-albumin conjugate: the ability to activate the glucagonlike peptide 1 receptor in vivo. Diabetes 52 751-759. (doi:10.2337/ diabetes.52.3.751)

Koehler JA, Baggio LL, Lamont BJ, Ali S \& Drucker DJ 2009 Glucagon-like peptide-1 receptor activation modulates pancreatitis-associated gene expression but does not modify the susceptibility to experimental pancreatitis in mice. Diabetes 58 2148-2161. (doi:10.2337/db09-0626)

Kwon DY, Kim YS, Ahn IS, Kim da S, Kang S, Hong SM \& Park S 2009 Exendin- 4 potentiates insulinotropic action partly via increasing $\beta$-cell proliferation and neogenesis and decreasing apoptosis in association with the attenuation of endoplasmic reticulum stress in islets of diabetic rats. Journal of Pharmacological Sciences 111 361-371. (doi:10.1254/jphs.09178FP)

Lamont BJ \& Drucker DJ 2008 Differential antidiabetic efficacy of incretin agonists versus DPP-4 inhibition in high fat fed mice. Diabetes $\mathbf{5 7}$ 190-198. (doi:10.2337/db07-1202)

Lamont BJ, Li Y, Kwan E, Brown TJ, Gaisano H \& Drucker DJ 2012 Pancreatic GLP-1 receptor activation is sufficient for incretin control of glucose metabolism in mice. Journal of Clinical Investigation 122 388-402. (doi:10.1172/JCI42497)

Lerch MM \& Gorelick FS 2013 Models of acute and chronic pancreatitis. Gastroenterology 144 1180-1193. (doi:10.1053/j.gastro.2012.12.043) http://joe.endocrinology-journals.org DOI: 10.1530/JOE-13-0577
(C) 2014 Society for Endocrinology Printed in Great Britain
Li Y, Hansotia T, Yusta B, Ris F, Halban PA \& Drucker DJ 2003 Glucagon-like peptide-1 receptor signaling modulates $\beta$ cell apoptosis. Journal of Biological Chemistry 278 471-478. (doi:10.1074/jbc.M209423200)

Li Y, Cao X, Li LX, Brubaker PL, Edlund H \& Drucker DJ $2005 \beta$-Cell Pdx1 expression is essential for the glucoregulatory, proliferative, and cytoprotective actions of glucagon-like peptide-1. Diabetes 54 482-491. (doi:10.2337/diabetes.54.2.482)

Lovshin JA \& Drucker DJ 2009 Incretin-based therapies for type 2 diabetes mellitus. Nature Reviews. Endocrinology 5 262-269. (doi:10.1038/nrendo. 2009.48)

Maedler K, Carr RD, Bosco D, Zuellig RA, Berney T \& Donath MY 2005 Sulfonylurea induced $\beta$-cell apoptosis in cultured human islets. Journal of Clinical Endocrinology and Metabolism 90 501-506. (doi:10.1210/jc.2004-0699)

Maida A, Hansotia T, Longuet C, Seino Y \& Drucker DJ 2009 Differential importance of glucose-dependent insulinotropic polypeptide vs glucagon-like peptide 1 receptor signaling for $\beta$ cell survival in mice. Gastroenterology 137 2146-2157. (doi:10.1053/j.gastro.2009.09.004)

Maiztegui B, Borelli MI, Madrid VG, Del Zotto H, Raschia MA, Francini F, Massa ML, Flores LE, Rebolledo OR \& Gagliardino JJ 2011 Sitagliptin prevents the development of metabolic and hormonal disturbances, increased $\beta$-cell apoptosis and liver steatosis induced by a fructose-rich diet in normal rats. Clinical Science 120 73-80. (doi:10.1042/ CS20100372)

Matveyenko AV \& Butler PC $2006 \beta$-Cell deficit due to increased apoptosis in the human islet amyloid polypeptide transgenic (HIP) rat recapitulates the metabolic defects present in type 2 diabetes. Diabetes 55 2106-2114. (doi:10.2337/db05-1672)

Matveyenko AV, Dry S, Cox HI, Moshtaghian A, Gurlo T, Galasso R, Butler AE \& Butler PC 2009 Beneficial endocrine but adverse exocrine effects of sitagliptin in the human islet amyloid polypeptide transgenic rat model of type 2 diabetes: interactions with metformin. Diabetes $\mathbf{5 8}$ 1604-1615. (doi:10.2337/db09-0058)

Movassat J, Saulnier C \& Portha B $1995 \beta$-Cell mass depletion precedes the onset of hyperglycaemia in the GK rat, a genetic model of non-insulindependent diabetes mellitus. Diabetes \& Metabolism 21 365-370.

Mu J, Woods J, Zhou YP, Roy RS, Li Z, Zycband E, Feng Y, Zhu L, Li C, Howard AD et al. 2006 Chronic inhibition of dipeptidyl peptidase-4 with a sitagliptin analog preserves pancreatic $\beta$-cell mass and function in a rodent model of type 2 diabetes. Diabetes 55 1695-1704. (doi:10.2337/db05-1602)

Mu J, Petrov A, Eiermann GJ, Woods J, Zhou YP, Li Z, Zycband E, Feng Y, Zhu L, Roy RS et al. 2009 Inhibition of DPP-4 with sitagliptin improves glycemic control and restores islet cell mass and function in a rodent model of type 2 diabetes. European Journal of Pharmacology $\mathbf{6 2 3}$ 148-154. (doi:10.1016/j.ejphar.2009.09.027)

Nachnani JS, Bulchandani DG, Nookala A, Herndon B, Molteni A, Pandya P, Taylor R, Quinn T, Weide L \& Alba LM 2010 Biochemical and histological effects of exendin-4 (exenatide) on the rat pancreas. Diabetologia 53 153-159. (doi:10.1007/s00125-009-1515-4)

Nauck MA 2013 A critical analysis of the clinical use of incretin-based therapies: the benefits by far outweigh the potential risks. Diabetes Care 36 2126-2132. (doi:10.2337/dc12-2504)

Noel RA, Braun DK, Patterson RE \& Bloomgren GL 2009 Increased risk of acute pancreatitis and biliary disease observed in patients with type 2 diabetes: a retrospective cohort study. Diabetes Care 32 834-838. (doi:10.2337/dc08-1755)

Nyborg NC, Molck AM, Madsen LW \& Knudsen LB 2012 The human GLP-1 analog liraglutide and the pancreas: evidence for the absence of structural pancreatic changes in three species. Diabetes 61 1243-1249. (doi:10.2337/db11-0936)

Omar BA, Vikman J, Winzell MS, Voss U, Ekblad E, Foley JE \& Ahren B 2013 Enhanced $\beta$ cell function and anti-inflammatory effect after chronic treatment with the dipeptidyl peptidase- 4 inhibitor vildagliptin in an advanced-aged diet-induced obesity mouse model. Diabetologia 56 1752-1760. (doi:10.1007/s00125-013-2927-8) 
Park S, Dong X, Fisher TL, Dunn S, Omer AK, Weir G \& White MF 2006 Exendin-4 uses Irs2 signaling to mediate pancreatic $\beta$ cell growth and function. Journal of Biological Chemistry 281 1159-1168. (doi:10.1074/ jbc.M508307200)

Parkes DG, Mace KF \& Trautmann ME 2013 Discovery and development of exenatide: the first antidiabetic agent to leverage the multiple benefits of the incretin hormone, GLP-1. Expert Opinion on Drug Discovery 8 219-244. (doi:10.1517/17460441.2013.741580)

Perfetti R, Zhou J, Doyle ME \& Egan JM 2000 Glucagon-like peptide-1 induces cell proliferation and pancreatic-duodenum homeobox-1 expression and increases endocrine cell mass in the pancreas of old, glucose-intolerant rats. Endocrinology 141 4600-4605. (doi:10.1210/ endo.141.12.7806)

Rankin MM \& Kushner JA 2009 Adaptive $\beta$-cell proliferation is severely restricted with advanced age. Diabetes 58 1365-1372. (doi:10.2337/ db08-1198)

Rankin MM, King KB, Kim JJ, Li C \& Kushner JA 2012 New $\beta$ cells are not generated by prolonged administration of incretin-based therapies (Exendin-4 or Sitagliptin) in adult mouse pancreas. Diabetes 61(suppl 1A) LB34.

Raschi E, Piccinni C, Poluzzi E, Marchesini G \& De Ponti F 2013 The association of pancreatitis with antidiabetic drug use: gaining insight through the FDA pharmacovigilance database. Acta Diabetologica 50 569-577. (doi:10.1007/s00592-011-0340-7)

Reimer MK, Holst JJ \& Ahren B 2002 Long-term inhibition of dipeptidyl peptidase IV improves glucose tolerance and preserves islet function in mice. European Journal of Endocrinology 146 717-727. (doi:10.1530/eje. $0.1460717)$

Rolin B, Larsen MO, Gotfredsen CF, Deacon CF, Carr RD, Wilken M \& Knudsen LB 2002 The long-acting GLP-1 derivative NN2211 ameliorates glycemia and increases $\beta$-cell mass in diabetic mice. American Journal of Physiology. Endocrinology and Metabolism 283 E745-E752. (doi:10.1152/ajpendo.00030.2002)

Sato K, Nakamura A, Shirakawa J, Muraoka T, Togashi Y, Shinoda K, Orime K, Kubota N, Kadowaki T \& Terauchi Y 2012 Impact of the dipeptidyl peptidase- 4 inhibitor vildagliptin on glucose tolerance and $\beta$-cell function and mass in insulin receptor substrate-2-knockout mice fed a high-fat diet. Endocrinology 153 1093-1102. (doi:10.1210/ en.2011-1712)

Shimizu S, Hosooka T, Matsuda T, Asahara S, Koyanagi-Kimura M, Kanno A, Bartolome A, Etoh H, Fuchita M, Teruyama K et al. 2012 DPP4 inhibitor vildagliptin preserves $\beta$-cell mass through amelioration of endoplasmic reticulum stress in C/EBPB transgenic mice. Journal of Molecular Endocrinology 49 125-135. (doi:10.1530/JME12-0039)

Shirakawa J, Amo K, Ohminami H, Orime K, Togashi Y, Ito Y, Tajima K, Koganei M, Sasaki H, Takeda E et al. 2011a Protective effects of dipeptidyl peptidase-4 (DPP-4) inhibitor against increased $\beta$ cell apoptosis induced by dietary sucrose and linoleic acid in mice with diabetes. Journal of Biological Chemistry 286 25467-25476. (doi:10.1074/ jbc.M110.217216)

Shirakawa J, Fujii H, Ohnuma K, Sato K, Ito Y, Kaji M, Sakamoto E, Koganei M, Sasaki H, Nagashima Y et al. 2011b Diet-induced adipose tissue inflammation and liver steatosis are prevented by DPP-4 inhibition in diabetic mice. Diabetes 60 1246-1257. (doi:10.2337/ db10-1338)

Singh S, Chang HY, Richards TM, Weiner JP, Clark JM \& Segal JB 2013 Glucagon-like peptide 1-based therapies and risk of hospitalization for acute pancreatitis in type 2 diabetes mellitus: a population-based matched case-control study. JAMA Internal Medicine 173 534-539. (doi:10.1001/jamainternmed.2013.2720)

Stamateris RE, Sharma RB, Hollern DA \& Alonso LC 2013 Adaptive $\beta$-cell proliferation increases early in high-fat feeding in mice, concurrent with metabolic changes, with induction of islet cyclin D2 expression. American Journal of Physiology. Endocrinology and Metabolism 305 E149-E159. (doi:10.1152/ajpendo.00040.2013)
Stoffers DA, Kieffer TJ, Hussain MA, Drucker DJ, Bonner-Weir S, Habener JF \& Egan JM 2000 Insulinotropic glucagon-like peptide 1 agonists stimulate expression of homeodomain protein IDX-1 and increase islet size in mouse pancreas. Diabetes 49 741-748. (doi:10.2337/ diabetes.49.5.741)

Stoffers DA, Desai BM, DeLeon DD \& Simmons RA 2003 Neonatal exendin-4 prevents the development of diabetes in the intrauterine growth retarded rat. Diabetes 52 734-740. (doi:10.2337/ diabetes.52.3.734)

Strobel O, Rosow DE, Rakhlin EY, Lauwers GY, Trainor AG, Alsina J, Fernandez-Del Castillo C, Warshaw AL \& Thayer SP 2010 Pancreatic duct glands are distinct ductal compartments that react to chronic injury and mediate Shh-induced metaplasia. Gastroenterology 138 1166-1177. (doi:10.1053/j.gastro.2009.12.005)

Sturis J, Gotfredsen CF, Romer J, Rolin B, Ribel U, Brand CL, Wilken M, Wassermann K, Deacon CF, Carr RD et al. 2003 GLP-1 derivative liraglutide in rats with $\beta$-cell deficiencies: influence of metabolic state on $\beta$-cell mass dynamics. British Journal of Pharmacology 140 123-132. (doi:10.1038/sj.bjp.0705397)

Takahashi A, Nagashima K, Hamasaki A, Kuwamura N, Kawasaki Y, Ikeda H, Yamada Y, Inagaki N \& Seino Y 2007 Sulfonylurea and glinide reduce insulin content, functional expression of K(ATP) channels, and accelerate apoptotic $\beta$-cell death in the chronic phase. Diabetes Research and Clinical Practice 77 343-350. (doi:10.1016/j.diabres. 2006.12.021)

Takeda Y, Fujita Y, Honjo J, Yanagimachi T, Sakagami H, Takiyama Y, Makino Y, Abiko A, Kieffer TJ \& Haneda M 2012 Reduction of both $\beta$ cell death and alpha cell proliferation by dipeptidyl peptidase- 4 inhibition in a streptozotocin-induced model of diabetes in mice. Diabetologia 55 404-412. (doi:10.1007/s00125-011-2365-4)

Tatarkiewicz K, Smith PA, Sablan EJ, Polizzi CJ, Aumann DE, Villescaz C, Hargrove DM, Gedulin BR, Lu MG, Adams L et al. 2010 Exenatide does not evoke pancreatitis and attenuates chemically induced pancreatitis in normal and diabetic rodents. American Journal of Physiology. Endocrinology and Metabolism 299 E1076-E1086. (doi:10.1152/ ajpendo.00479.2010)

Tatarkiewicz K, Belanger P, Gu G, Parkes D \& Roy D 2013 No evidence of druginduced pancreatitis in rats treated with exenatide for 13 weeks. Diabetes, Obesity \& Metabolism 15 417-426. (doi:10.1111/dom.12040)

Tourrel C, Bailbe D, Meile MJ, Kergoat M \& Portha B 2001 Glucagon-like peptide- 1 and exendin- 4 stimulate $\beta$-cell neogenesis in streptozotocintreated newborn rats resulting in persistently improved glucose homeostasis at adult age. Diabetes 50 1562-1570. (doi:10.2337/ diabetes.50.7.1562)

Tourrel C, Bailbe D, Lacorne M, Meile MJ, Kergoat M \& Portha B 2002 Persistent improvement of type 2 diabetes in the Goto-Kakizaki rat model by expansion of the $\beta$-cell mass during the prediabetic period with glucagon-like peptide-1 or exendin-4. Diabetes 51 1443-1452. (doi:10.2337/diabetes.51.5.1443)

Trumper A, Trumper K \& Horsch D 2002 Mechanisms of mitogenic and anti-apoptotic signaling by glucose-dependent insulinotropic polypeptide in $\beta$ (INS-1)-cells. Journal of Endocrinology 174 233-46. (doi:10.1677/joe.0.1740233)

Tschen SI, Dhawan S, Gurlo T \& Bhushan A 2009 Age-dependent decline in $\beta$-cell proliferation restricts the capacity of $\beta$-cell regeneration in mice. Diabetes 58 1312-1320. (doi:10.2337/db08-1651)

Ussher JR \& Drucker DJ 2012 Cardiovascular biology of the incretin system. Endocrine Reviews 33 187-215. (doi:10.1210/er.2011-1052)

Verchere CB, D'Alessio DA, Palmiter RD, Weir GC, Bonner-Weir S, Baskin DG \& Kahn SE 1996 Islet amyloid formation associated with hyperglycemia in transgenic mice with pancreatic $\beta$ cell expression of human islet amyloid polypeptide. PNAS 93 3492-3496. (doi:10.1073/ pnas.93.8.3492)

Vrang N, Jelsing J, Simonsen L, Jensen AE, Thorup I, Soeborg H \& Knudsen LB 2012 The effects of $13 \mathrm{wk}$ of liraglutide treatment on endocrine and exocrine pancreas in male and female ZDF rats: a quantitative 
and qualitative analysis revealing no evidence of drug-induced pancreatitis. American Journal of Physiology. Endocrinology and Metabolism 303 E253-E264. (doi:10.1152/ajpendo.00182.2012)

Wang Q \& Brubaker PL 2002 Glucagon-like peptide-1 treatment delays the onset of diabetes in 8 week-old $d b / d b$ mice. Diabetologia 45 1263-1273. (doi:10.1007/s00125-002-0828-3)

Wang X, Cahill CM, Pineyro MA, Zhou J, Doyle ME \& Egan JM 1999 Glucagon-like peptide-1 regulates the $\beta$ cell transcription factor, PDX-1, in insulinoma cells. Endocrinology 140 4904-4907. (doi:10.1210/ endo.140.10.7158)

Wang Q, Li L, Xu E, Wong V, Rhodes C \& Brubaker PL 2004 Glucagon-like peptide-1 regulates proliferation and apoptosis via activation of protein kinase B in pancreatic INS-1 $\beta$ cells. Diabetologia 47 478-487. (doi:10.1007/s00125-004-1327-5)
Xu G, Stoffers DA, Habener JF \& Bonner-Weir S 1999 Exendin-4 stimulates both $\beta$-cell replication and neogenesis, resulting in increased $\beta$-cell mass and improved glucose tolerance in diabetic rats. Diabetes $\mathbf{4 8}$ 2270-2276. (doi:10.2337/diabetes.48.12.2270)

Yeom JA, Kim ES, Park HS, Ham DS, Sun C, Kim JW, Cho JH \& Yoon KH 2011 Both sitagliptin analogue \& pioglitazone preserve the $\beta$-cell proportion in the islets with different mechanism in non-obese and obese diabetic mice. BMB Reports 44 713-718. (doi:10.5483/ BMBRep.2011.44.11.713)

Zhang X, Wang Z, Huang Y \& Wang J 2011 Effects of chronic administration of alogliptin on the development of diabetes and $\beta$-cell function in high fat diet/streptozotocin diabetic mice. Diabetes, Obesity \& Metabolism 13 337-347. (doi:10.1111/j.1463-1326. 2010.01354.x)

Received in final form 7 January 2014

Accepted 14 January 2014

Accepted Preprint published online 14 January 2014
Published by Bioscientifica Ltd 